\title{
A tribo Senecioneae (Asteraceae) em Minas Gerais, Brasil
}

\author{
The tribe Senecioneae (Asteraceae) in Minas Gerais, Brazil
}

Aristônio M. Teles ${ }^{1,3}$ \& João Renato Stehmann ${ }^{2}$

\begin{abstract}
Resumo
Senecioneae está representada em Minas Gerais por oito gêneros e 41 espécies (Dendrophorbium 3 spp., Emilia 2 spp., Erechtites 3 spp., Graphistylis 5 spp., Hoehnephytum 1 sp., Pentacalia 1 sp., Pseudogynoxys 1 sp. e Senecio 25 spp.). Três espécies são culvitadas como ornamentais: Curio rowleyanus, Senecio flaccidus e S. tamoides. Seis espécies são novas ocorrências para o estado: Dendrophorbium fastigiaticephalum, Graphistylis argyrotricha, Senecio paulensis, S. paucijugus, S. pseudostigophlebius e S. stigophlebius. São apresentadas chaves de identificação para os gêneros e espécies, descrições, comentários sobre a taxonomia, distribuição geográfica e habitat, além de ilustrações das espécies estudadas.

Palavras-chave: Biodiversidade, Compositae, flora, Senecio.
\end{abstract}

\begin{abstract}
Senecioneae is represented in Minas Gerais, Southeastern Brazil, by eight genera and 41 species (Dendrophorbium 3 spp., Emilia 2 spp., Erechtites 3 spp., Graphistylis 5 spp., Hoehnephytum 1 sp., Pentacalia 1 sp., Pseudogynoxys 1 sp., and Senecio 25 spp.). Three species are cultivated as ornamental: Curio rowleyanus, Senecio flaccidus and S. tamoides. Six species are new occurrences: Dendrophorbium fastigiaticephalum, Graphistylis argyrotricha, S. paulensis, S. paucijugus, S. pseudostigophlebius and S. stigophlebius. Identification key of genera and species from Minas Gerais, descriptions, and comments on the taxonomy, geographical distribution and habitats, besides illustrations are given.
\end{abstract}

Key words: Biodiversity, Compositae, flora, Senecio.

\section{Introdução}

Senecioneae Cass. é a maior tribo em número de espécies entre as Asteraceae, com cerca de 3.500 espécies agrupadas em 150 gêneros (Nordenstam et al. 2009), sendo que aproximadamente um terço destas ocorrem no Novo Mundo (Hind 1993). Além de ser a maior tribo, ainda abriga o maior gênero da família em número de espécies, Senecio L., com aproximadamente 1250 espécies (Bremer 1994; Nordenstam 2007).

A tribo Senecioneae é praticamente cosmopolita, com exceção dos pólos, e concentram-se predominante na América do Sul e Central, África do Sul e tropical, além da porção central e oriental da Ásia e são bastante variáveis em hábito, podendo ser encontradas ervas, subarbustos, arbustos, lianas e árvores (Bremer 1994). Em relação aos tipos de habitats, as espécies podem ser encontradas, desde ambientes aquáticos até desérticos, de baixas altitudes a comunidades alpinas, e desde regiões árticas até tropicais (Bremer 1994; Pelser et al. 2007).

No Brasil, são encontradas 95 espécies distribuídas em oito gêneros: Dendrophorbium (Cuatrec.) C. Jeffrey, Emilia (Cass.) Cass., Erechtites Raf., Graphistylis B. Nord., Hoehnephytum Cabrera, Pentacalia Cass., Pseudogynoxys (Greenm.) Cabrera e Senecio (BFG 2015) e estudos taxonômicos com a tribo são escassos, podendo-se citar os trabalhos de Baker (1884), Cabrera (1957), Cabrera \& Klein

\footnotetext{
${ }^{1}$ Universidade Federal de Goiás, Inst. Ciências Biológicas, Depto. Botânica, campus Samambaia, saída para Nerópolis Km 13, 74001-970, Goiânia, GO, Brasil.

${ }^{2}$ Universidade Federal de Minas Gerais, Inst. Ciências Biológicas, Depto. Botânica, Av. Antônio Carlos 6627, Pampulha, 31270-901, Belo Horizonte, MG, Brasil.

${ }^{3}$ Autor para correspondência: teles@ufg.br
} 
(1975), Matzenbacher (1998) e Teles \& Stehmann (2011). A partir do trabalho de Cabrera (1957), novos táxons foram descritos (e.g., Zardini 1979; Robinson 1980; Matzenbacher 1996, 2009; Teles et al. 2006, 2009; Teles \& Meireles 2010; Teles \& Freitas 2013), combinados (e.g., Nordenstam 1994; Matzenbacher \& Baptista 1997; Teles 2010) e acrescidos à lista da flora brasileira.

No presente trabalho é apresentado o tratamento taxonômico para as espécies de Senecioneae ocorrentes no estado de Minas Gerais, com a apresentação de chaves e descrições para a identificação de gêneros e espécies, além de comentários sobre taxonomia e distribuição geográfica de cada táxon, bem como ilustrações.

\section{Material e Métodos}

O presente trabalho teve como fonte os materiais depositados nos herbários ALCB, BHCB, CESJ, ESA, HRB, HUEFS, HUFU, ICN, K, MBM, MBML, P, PAMG, RB, SPF e UEC (Thiers 2015). As informações obtidas a partir da análise de exsicatas foram complementadas com coletas e observações do primeiro autor. As coletas foram feitas ao longo de quatro anos em diversas localidades de Minas Gerais e seguiram o método de caminhamento (Filgueiras et al. 1994), com frequência e duração variáveis. Todo material coletado foi processado seguindo-se as técnicas usuais em taxonomia vegetal (Bridson \& Forman 1992) e incorporado ao acervo do herbário do Instituto de Ciências Biológicas da Universidade Federal de Minas Gerais (herbário BHCB).

As características descritas para a tribo foram baseadas em Nordenstam (2007), porém adaptadas para os táxons ocorrentes no Brasil, enquanto que as características genéricas e específicas dizem respeito a aquelas encontradas nas espécies examinadas procedentes de Minas Gerais. A análise morfológica baseou-se em material herborizado. As observações e medidas das estruturas florais foram feitas com o auxílio de estereomicroscópio, após reidratação do material por fervura em água. A análise micromorfológica (tricomas, células do colar da antera e do tecido endotecial, além do ápice dos ramos do estilete) foi feita a partir da reidratação por fervura, seguida de diafanização em hidróxido de sódio $(\mathrm{NaOH})$ a $5 \%$. Após diafanizadas, as estruturas foram montadas em lâminas provisórias e analisadas em microscópio óptico.

A distribuição das espécies no Brasil está baseada em Belcher (1956), Cabrera (1957),
Hind (1993, 1999), Matzenbacher (1998), Teles et al. (2006), Teles \& Stehmann (2008), e complementada com as informações compiladas das fichas das exsicatas dos herbários visitados.

Não foram levadas em consideração as categorias taxonômicas infraespecíficas, tais como variedades e formas; apenas são feitos comentários para os táxons que possuem essas categorias.

\section{Resultados e Discussão}

BFG (2015) reportam para o Brasil a ocorrência de 95 espécies de Senecioneae agrupadas em oito gêneros. Em Minas Gerais a tribo Senecioneae está representada por 41 espécies agrupadas nos oito gêneros que são reportados para o país. Três espécies são cultivadas como ornamentais: Curio rowleyanus (H. Jacobsen) P.V. Heath, Senecio flaccidus Less. e $S$. tamoides DC.

\section{Senecioneae Cass.}

Ervas, arbustos, lianas ou árvores. Folhas alternas, em roseta ou ao longo dos ramos, sésseis ou pecioladas, inteiras ou variadamente sectadas. Capítulos radiados, disciformes ou discoides, heterógamos ou homógamos, flores com corola geralmente amarela, algumas vezes alvacenta, alaranjada, rosada, vermelha ou lilás. Capítulos solitários ou dispostos em capitulescências corimbiformes, paniculiformes ou tirsoides, terminais ou laterais. Invólucro unisseriado, campanulado, cilíndrico ou urceolado, caliculado ou ecaliculado. Brácteas involucrais livres ou conatas. Eixo da inflorescência, plano, convexo ou cônico, desprovido de projeções ou fimbriado a denticulado, piloso ou glabro, sólido ou fistuloso. Flores do raio pistiladas; corola liguliforme ou filiforme. Flores do disco perfeitas; corola tubulosa, 5-lobada. Estames 5, anteras com apêndice do conectivo oblongo, base obtusa, sagitada ou caudada; tecido endotecial radial ou polarizado, raramente transicional; colar da antera reto, basalmente dilatado (balustriforme) com longas células. Estilete bífido, apicalmente truncado, obtuso, arredondado ou triangular, algumas vezes longamente acuminado com tricomas fusionados ou com distinto tufo de tricomas; áreas estigmáticas contínuas ou separadas. Cipselas costeladas, cilíndricas ou obovoides, glabras ou variavelmente pubescentes. Pápus cerdoso, 1-multisseriado, cerdas persistentes ou caducas, finas, alvacentas, estramíneas, ou púrpuras. 


\section{Chave de identificação para os gêneros de Senecioneae ocorrentes em Minas Gerais}

1. Capítulos discoides; brácteas involucrais e flores do capítulo em número de 5.........5. Hoehnephytum

1'. Capítulos disciformes, radiados ou discoides, porém, se discoides, com brácteas involucrais e flores do capítulo em número maior que 5 .

2. Capítulos disciformes, flores da margem com corola longamente filiforme

3. Erechtites

2'. Capítulos radiados, flores do raio com corola distintamente liguliforme, e/ou capítulos discoides, com todas as flores de corola tubulosa.

3. Ramos do estilete com ápice truncado, convexo ou rômbico.

4. Capítulos discoides

8. Senecio

4'. Capítulos radiados.

5. Ramos do estilete com ápice convexo.

1. Dendrophorbium

5'. Ramos do estilete com ápice rômbico ou truncado.

6. Plantas escandentes; ramos do estilete com ápice rômbico

6. Pentacalia

6'. Plantas eretas, prostradas ou decumbentes; ramos do estilete com ápice truncado. 8. Senecio

3'. Ramos do estilete com ápice truncado, com conspícuo tufo de tricomas partindo do centro, ou apendiculado, longamente acuminado, com tricomas fusionados ou apêndice penicilado.

7. Ramos do estilete com ápice truncado, com conspícuo tufo de tricomas partindo do centro, circundado por coroa de tricomas curtos, divergentes 4. Graphistylis

7'. Ramos do estilete com ápice apendiculado, longamente acuminado, com tricomas fusionados ou apêndice penicilado, sem coroa de tricomas divergentes.

8. Subarbustos a arbustos escandentes, perenes; capítulos radiados; invólucro caliculado; ramos do estilete com ápice longamente acuminado, com tricomas fusionados..... 7. Pseudogynoxys

8'. Ervas eretas, anuais; capítulos discoides; invólucro ecaliculado; ramos do estilete com ápice com apêndice penicilado. 2. Emilia

\section{Dendrophorbium (Cuatrec.) C. Jeffrey, Kew} Bull. 47: 65. 1992.

Ervas, subarbustos, arbustos ou raramente árvores, eretos ou raramente escandentes, perenes. Caule simples a escassamente ramificado. Lâminas foliares elípticas, lanceoladas, oblanceoladas, ovadas ou ovado-lanceoladas, ápice agudo ou acuminado, base atenuada, obtusa ou cordada, margem denticulada, serreada, ou inteira, peninérveas, pecíolos ocasionalmente alados. Capítulos heterógamos, radiados, dispostos em capitulescências fastigiadas ou paniculiformes. Invólucro campanulado, caliculado ou ecaliculado; brácteas involucrais $6-15$. Flores do raio $4-8$, pistiladas, corola liguliforme, amarelas. Flores do disco 6-17, perfeitas, corola tubulosa, amarela. Anteras com base obtusa, ecaudadas, raro caudadas. Ramos do estilete com ápice convexo, envolto por uma coroa de tricomas divergentes. Cipselas cilíndricas ou obcônicas, 8-10-costeladas, glabras. Pápus alvacento, caduco ou persistente.

Dendrophorbium é um gênero predominantemente andino (Jeffrey 1992), com aproximadamente 75 espécies que ocorrem na Argentina, Bolívia, Brasil, Paraguai e Venezuela (Nordenstam 2007). As espécies de Dendrophorbium ocorrentes no Brasil foram agrupadas por Cabrera (1957) em Senecio sect. Myriocephalus Cabrera, porém Jeffrey (1992) quando elevou Dendrophorbium à categoria taxonômica de gênero subordinou a seção Myriocephalus à sinonímia de Dendrophorbium e propôs novas combinações no referido gênero. No Brasil o gênero está representador por 12 espécies (Teles 2010; BFG 2015) e em Minas Gerais por três.

\section{Chave de identificação para as espécies de Dendrophorbium ocorrentes em Minas Gerais}

1. Ervas a arbustos; lâminas foliares glabras na face abaxial; flores do disco 6-11.

2. Folhas com margem serreada apenas na metade superior da lâmina; capitulescência densamente fastigiada; flores do raio 4-5, limbo 7-10 mm compr. 1.1. D. fastigiaticephalum 
2'. Folhas com margem inteira ou serreada por toda a extensão; capitulescência paniculiforme; flores do raio 6-8, limbo 4-4,5 $\mathrm{mm}$ compr. 1.3. D. pellucidinerve 1'. Árvores; lâminas foliares densamente albo ou amarelo-tomentosas na face abaxial; flores do disco $12-17$. 1.2. D. glaziovii

\subsection{Dendrophorbium fastigiaticephalum (Cabrera) C. Jeffrey, Kew Bull. 47: 66. 1992.}

Fig. 1a

Ervas eretas, perenes, $0,5-1,5 \mathrm{~m}$ alt. Caule multisulcado, fistuloso, densamente folhoso por toda a extensão, glabro. Lâminas foliares 3,5-6,6 $\times 0,5-1,2 \mathrm{~cm}$, oblanceoladas a lanceoladas, ápice agudo, acuminado, base atenuada formando um pseudopecíolo, margem serreada na metade superior da lâmina, planas a revolutas, peninérveas em ambas as faces, nervuras secundárias finamente reticuladas na face adaxial, nervuras conspícuas, glabras em ambas as faces. Capitulescência densamente fastigiada, congesta. Capítulos com pedúnculos 8-12 mm compr., bracteolados, glabros; bractéolas lanceoladas, 2,8-3,5 $\mathrm{mm}$ compr., ciliadas. Invólucro 7-8 × 5-9 mm, ecaliculado; brácteas involucrais 7-8, lanceoladas, ápice agudo, piloso, margem escariosa, dorso glabro; eixo da inflorescência plano, alveolado. Flores do raio 4-5, corola amarela, tubo $3,5-5$ mm compr., limbo 7-10 × ca. 1,5 mm, 4-nervada, ápice 3-dentado, estilete ca. $7 \mathrm{~mm}$ compr., ramos do estilete ca. $1 \mathrm{~mm}$ compr. Flores do disco 8-11, corola 7-8 mm compr., 5-lobulada, lóbulos ca. 1 $\mathrm{mm}$ compr., anteras ca. 1,6 mm compr., exsertas, apêndice do conectivo oblongo, ca. 0,5 mm compr.; estilete ca. $9 \mathrm{~mm}$ compr., ramos do estilete ca. $1 \mathrm{~mm}$ compr. Cipselas 2,2-2,5 mm compr., cilíndricas, 8-costeladas, glabras; pápus 6-7 $\mathrm{mm}$ compr., persistente.

Material examinado: Catas Altas, Serra do Caraça, 1816-1821, A. Saint-Hilaire 1379 (P). Poços de Caldas, Morro do Ferro, 24.III.1967, O. Leoncini 1022 (RB).

Ocorre em Minas Gerais e São Paulo em campo rupestre, entre 1.400 e 1.540 m.s.m. Fértil em março.

Dendrophorbium fastigiaticephalum foi considerado por Cabrera (1957) e Hind (1993) como endêmica para o estado de São Paulo, porém tivemos a oportunidade de examinar material proveniente de Catas Altas e de Poços de Caldas, registrando a espécie pela primeira vez para o estado de Minas Gerais. Ao que parece trata-se de uma espécie rara não apenas em Minas Gerais, mas também em São Paulo, uma vez que há poucas e antigas coletas da espécie encontradas nos herbários visitados. Esta espécie é bem distinta das demais espécies do gênero por apresentar capitulescência densamente fastigiada.

1.2 Dendrophorbium glaziovii (Baker) C. Jeffrey, Kew Bull. 47: 67. 1992.

Fig. $1 \mathrm{~b}$

Árvores, 4-9 m alt. Tronco ca. $30 \mathrm{~cm}$ diâm. Ramos densamente folhosos por toda a extensão, albo ou amarelo-tomentosos. Lâminas foliares $12-25 \times 6-12 \mathrm{~cm}$, ovadas a elípticas, ápice agudo, acuminado, base obtusa, margem inteira a denticulada, peninérveas, glabrescentes na face adaxial, densamente albo ou amarelo-tomentosas na face abaxial; pecíolos 3-7 cm compr., densamente tomentosos. Capitulescência paniculiforme, laxa. Capítulos com pedúnculos 3-10 $\mathrm{cm}$ compr., tomentosos; bractéolas lanceoladas, 3-4 $\mathrm{mm}$ compr., tomentosas. Invólucro 5-6 × 3-5 mm, caliculado; brácteas do calículo 5 , lanceoladas, 3-5 mm compr., lanosas; brácteas involucrais 6-8, oblongas, ápice agudo, piloso, margem escariosa, dorso glabro; eixo da inflorescência plano, alveolado. Flores do raio 4-5, corola creme, tubo 3-5 mm compr., limbo 2-3,5 × ca. $1 \mathrm{~mm}, 2$-nervada, ápice 3-dentado, estilete ca. $8 \mathrm{~mm}$ compr., ramos do estilete ca. $2 \mathrm{~mm}$ compr. Flores do disco 12-17, corola 7-8 mm compr., 5-lobulada, lóbulos ca. 1,5 $\mathrm{mm}$ compr., anteras ca. $2 \mathrm{~mm}$ compr., exsertas, apêndice do conectivo oblongo-deltóide, ca. 0,5 $\mathrm{mm}$ compr.; estilete ca. $10 \mathrm{~mm}$ compr., ramos do estilete ca. $2 \mathrm{~mm}$ compr. Cipselas 2-2,5 mm compr., cilíndricas, 8-costeladas, glabras; pápus 6-7 mm compr., persistente.

Material selecionado: Camanducaia, $22^{\circ} 42^{\prime} 50^{\prime \prime}$, 45056'12"W, 24.VIII.2000, L.H.Y. Kamino et al. 106 (BHCB). Delfim Moreira, $1.500 \mathrm{~m}, 24$. VIII.2005, F.A.R.D.P. Arzolla \& J.B. Pinto 939 (UEC). Poços de Caldas, 21050'20"S, 463' 53”'W, 4.IX.1980, H.F. Leitão Filho et al. 81 (UEC).

Ocorre em Minas Gerais, Rio de Janeiro e São Paulo em formações florestais ombrófilas montanas. Fértil de julho a outubro.

Dendrophorbium glaziovii é uma espécie bastante característica, talvez a única espécie de Senecioneae ocorrente no Brasil com hábito 
arbóreo. Além do hábito, difere das demais espécies pelas folhas albo ou amarelotomentosas abaxialmente, característica essa compartilhada apenas com $D$. brachycodon Baker (Baker) C. Jeffrey, ocorrente em São Paulo e no Paraná.
1.3 Dendrophorbium pellucidinerve (Sch. Bip. ex Baker) C. Jeffrey, Kew Bull. 47: 68. 1992.

Fig. 1c-g

Subarbustos a arbustos eretos ou escandentes, perenes, 0,5-1 $\mathrm{m}$ alt. Caule multisulcado, meduloso, densamente folhoso

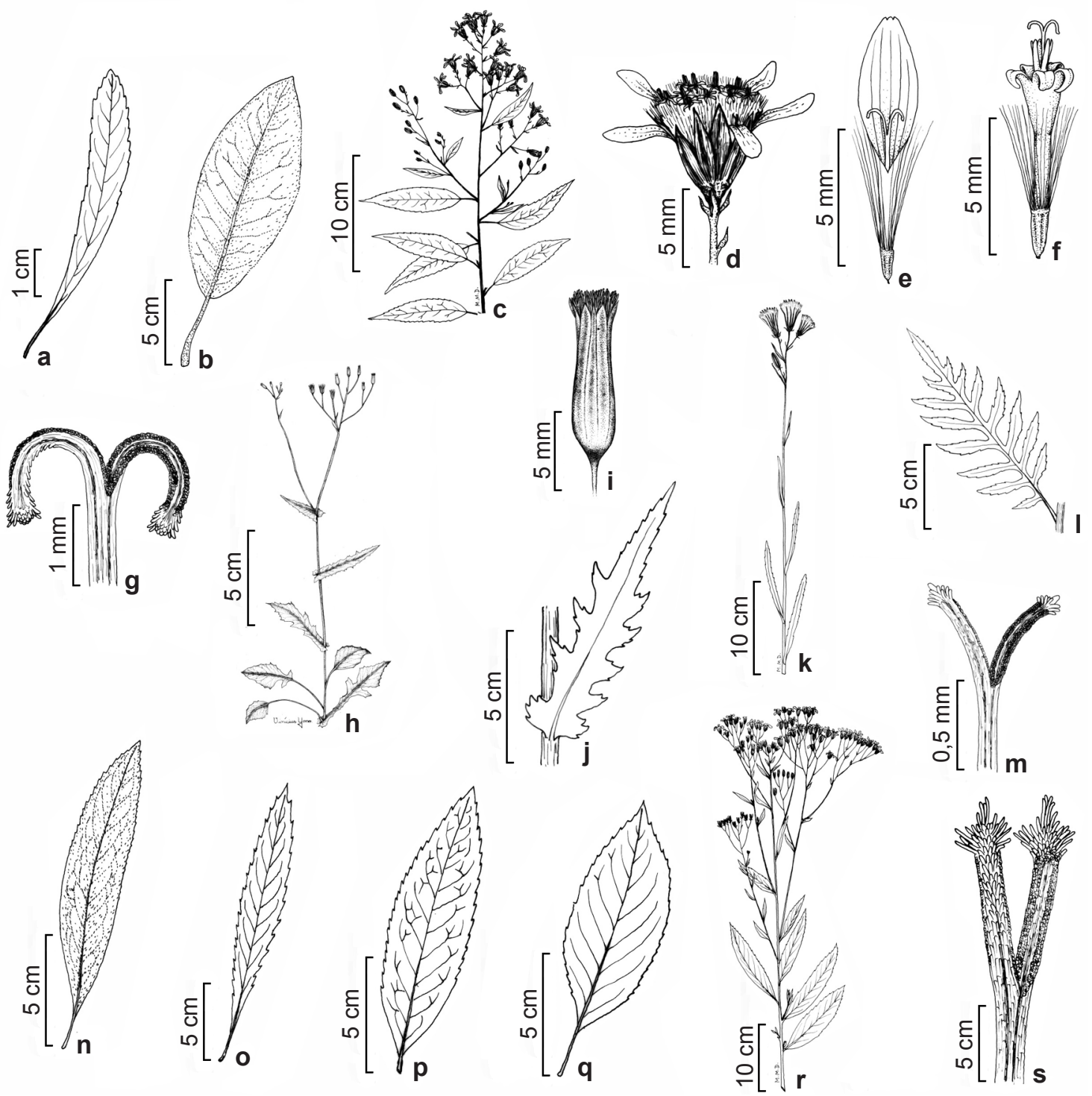

Figura 1 - a. Dendrophorbium fastigiaticephalum - folha. b. Dendrophorbium glaziovii - folha. c-g. Dendrophorbium pellucidinerve - c. ramo florido; d. capítulo; e. flor do raio; f. flor do disco; g. ramos do estilete. h-i. Emilia sonchifolia - h. hábito; i. capítulo. j. Erechtites hieracifolius - folha. k. Erechtites ignobilis - hábito. 1-m. Erechtites valerianifolius - 1. folha; m. ramos do estilete. n. Graphistylis argyrotricha - folha. o. Graphistylis dichroa - folha. p. Graphistylis itatiaiae - folha. q. Graphistylis organensis - folha. r-s. Graphistylis riopretensis - r. ramo florido; s. ramos do estilete.

Figure 1 - a. Dendrophorbium fastigiaticephalum - leaf. b. Dendrophorbium glaziovii - leaf. c-g. Dendrophorbium pellucidinerve-c. flowering branch; d. capitula; e. ray floret; f. disc floret; g. style branches. h-i. Emilia sonchifolia - h. habit; i. capitula. j. Erechtites hieracifolius - leaf. k. Erechtites ignobilis - habit. 1-m. Erechtites valerianifolius -1. leaf; m. style branches. n. Graphistylis argyrotricha - leaf. o. Graphistylis dichroa - leaf. p. Graphistylis itatiaiae - leaf. q. Graphistylis organensis - leaf. r-s. Graphistylis riopretensis - r. flowering branch; s. style branches. 
por toda a extensão, glabro. Lâminas foliares $2,5-9 \times 0,8-4,5 \mathrm{~cm}$, ovadas ou elípticas, ápice agudo, acuminado, base obtusa, margem inteira a serreada, peninérveas, nervuras terciárias finamente reticuladas, glabras em ambas as faces; pecíolos 1-2 cm compr., glabros. Capitulescência paniculiforme, congesta. Capítulos com pedúnculos $3-13 \mathrm{~mm}$ compr., lanuginosos; bractéolas lanceoladas, 3-4 $\mathrm{mm}$ compr., glabras. Invólucro $5-6 \times$ ca. $5 \mathrm{~mm}$, caliculado; brácteas do calículo 4 , ca. $2,5 \mathrm{~mm}$ compr., lanceoladas; brácteas involucrais 7-8, oblongas, ápice agudo, piloso, margem escariosa, dorso glabro; eixo da inflorescência plano, alveolado. Flores do raio 6-8, corola amarela, tubo $2-3 \mathrm{~mm}$ compr., limbo $4-4,5 \times 1,5 \mathrm{~mm}$, 4-nervada, ápice 2-3-dentado, estilete 4-4,5 $\mathrm{mm}$ compr., ramos do estilete ca. 1,5 mm compr. Flores do disco 6-9, corola ca. $6 \mathrm{~mm}$ compr., 5-lobulada, lóbulos ca. 1,5 mm compr., anteras ca. 2,5 mm compr., exsertas, apêndice do conectivo ca. $0,5 \mathrm{~mm}$ compr., oblongo-deltoide; estilete ca. $5 \mathrm{~mm}$ compr., ramos do estilete ca. $2 \mathrm{~mm}$ compr. Cipselas ca. 1,5 mm compr., cilíndricas a obcônicas, 8-costeladas, glabras; pápus 4-5 mm compr., persistente.

Material selecionado: Itamonte, $2.100 \mathrm{~m}, 22^{\circ} 22^{\prime} 17,4^{\prime \prime} \mathrm{S}$, 44²7'24,3”W, 20.VII.2005, L.D. Meireles et al. 1859 (BHCB, UEC). Lima Duarte, $1.670 \mathrm{~m}, 21^{\circ} 40^{\prime} 44^{\prime \prime} \mathrm{S}$, 43052'59"W, 11.VIII.2005, R.C. Forzza et al. 4153 (BHCB, RB). Rio Preto, 21.VIII.2004, C.N. Matozinhos et al. 42 (BHCB, CESJ).

Ocorre no Rio de Janeiro e São Paulo, em campos rupestres com afloramentos quartzíticos e em campos de altitude, de 1.300 a 2.100 m.s.m. Fértil de maio a outubro.

Dendrophorbium pellucidinerve caracterizase pelas folhas com lâminas foliares ovadas a elípticas, conspicuamente pecioladas e com finas nervuras reticuladas.

2. Emilia (Cass.) Cass., Dict. Sc. Nat. 34: 393. 1825.

Ervas eretas, anuais. Caule simples. Lâminas foliares ovadas, obovado-lanceoladas ou lanceoladas, ápice agudo a obtuso; base atenuada ou cordada, margem denteada, peninérveas, sésseis ou pecioladas, pecíolos ocasionalmente alados. Capítulos homógamos, discoides, dispostos em capitulescências corimbiformes. Invólucro urceolado, ecaliculado, brácteas involucrais 6-14, conatas. Flores 15-50, perfeitas, corola estreitamente tubulosa, com leve dilatação apical, vermelhas ou róseas. Anteras com base obtusa. Ramos do estilete com ápice com apêndice penicilado. Cipselas cilíndricas, 10-costeladas, híspidas entre as costelas. Pápus alvacento, persistente.

Emilia é reconhecível pelos capítulos discoides com flores vermelhas ou róseas, pelo invólucro de brácteas involucrais conatas e pela ausência de calículo. As folhas são bastante variáveis, mas geralmente as basais são pecioladas, enquanto as caulinares são sésseis, algumas vezes invaginantes (Nicolson 1980). O gênero conta com cerca de 100 espécies distribuídas principalmente na África (Nordenstam 2007). No Brasil são encontradas apenas duas espécies que possuem distribuição pantropical: Emilia fosbergii Nicolson e E. sonchifolia (L.) DC., (BFG 2015), ambas encontradas em Minas Gerais.

\section{Chave de identificação para as espécies de Emilia ocorrentes em Minas Gerais}

1. Folhas basais com lâmina obovada a obovado-lanceolada; brácteas involucrais 10-14; corola avermelhada; lóbulos da corola $1-1,5 \mathrm{~mm}$ compr. 2.1. E. fosbergii

1'. Folhas basais com lâmina lirado-lobada; brácteas involucrais 6-8; corola rosada; lóbulos da corola $0,5-0,7 \mathrm{~mm}$ compr. 2.2. E. sonchifolia

2.1 Emilia fosbergii Nicolson, Phytologia 32: 34. 1975 .

Ervas eretas, anuais, $0,2-1 \mathrm{~m}$ alt. Caule liso, meduloso, densamente folhoso na porção basal, laxamente folhoso na porção apical, glabro ou esparsamente pubescente. Folhas basais com lâmina 3-15 × 1-6,5 cm, obovada a obovadolanceolada, ápice obtuso a arredondado, base atenuada, margem fortemente denteada, pecioladas, glabra a esparsamente pubescente em ambas as faces. Folhas apicais gradativamente menores, lâmina lanceolada, ápice agudo, base cordada ou sagitada, amplexicaules, glabra a esparsamente pubescente em ambas as faces. Capítulos com pedúnculos $0,6-5,5 \mathrm{~cm}$ compr., ebracteolados, glabros a esparsamente 
pubescentes. Invólucro 7-15 × 5-9 $\mathrm{mm}$, largamente cilíndrico; brácteas involucrais 1014, lineares, ápice agudo, glabro ou piloso, dorso glabro; eixo da inflorescência plano, alveolado. Flores 20-50, corola vermelha, ca. $7 \mathrm{~mm}$ compr., 5-lobuladas, lóbulos 1-1,5 mm compr.; anteras ca. $1,5 \mathrm{~mm}$ compr., inclusas, apêndice do conectivo ca. $0,3 \mathrm{~mm}$ compr., oblongo; estilete ca. 7,5 mm compr., ramos do estilete ca. $1 \mathrm{~mm}$ compr. Cipselas 2-4 mm compr., híspidas entre as costelas; pápus 6-7 mm compr.

Material selecionado: Brumadinho, $20^{\circ} 06^{\prime} \mathrm{S}$, 4359'W, 1.400 m, 14.III.1999, V.M. Silveira 179 (BHCB). Januária, $15^{\circ} 09^{\prime} 04^{\prime} \mathrm{S}, 44^{\circ} 13$ '58"W, 16.II.1998, J.A. Lombardi \& L.G. Temponi 2217 (BHCB). São Gonçalo do Rio Preto, $18^{\circ} 05^{\prime} 28^{\prime} \mathrm{S}$, 4320'32"W, 7.IV.2000, J.A. Lombardi \& A.C.M. Lara 3747 (BHCB).

Espécie amplamente distribuída nos neotrópicos e recentemente introduzida na região do Pacífico (Pruski 1997). No Brasil ocorre em todos os estados como ruderal. Fértil durante todo o ano.

Emilia fosbergii difere da sua espécie mais próxima (E. sonchifolia) principalmente pelas flores vermelhas (versus róseas) e pelas flores que geralmente são excertas em relação ao invólucro do capítulo.

Iconografias em Nicolson (1980: 393, fig. 2), Pruski (1997: 270, fig. 226) e Moraes \& Monteiro (2006: 45, fig. 5).

Nomes vernaculares: emília, falsa-serralha, pincel, pincel-de-estudante, serralha.

2.2 Emilia sonchifolia (L.) DC., Contr. Bot. India 24. 1834.

Fig. 1h-i

Ervas eretas, anuais, 0,1-0,5 m alt. Caule liso, meduloso, densamente folhoso na porção basal, laxamente folhoso na porção apical, glabro ou esparsamente pubescente. Folhas basais com lâmina 2-4 × 10,9-2 cm, lirado-lobada, ápice obtuso a arredondado, base atenuada em pseudopeciolo, glabra a esparsamente pubescente em ambas as faces. Folhas apicais gradativamente menores, lâmina lanceolada a deltoide, ápice agudo, base cordada ou sagitada, amplexicaule, glabra a esparsamente pubescente em ambas as faces. Capítulos com pedúnculos 0,2-1,5 cm compr., ebracteolados, glabros a esparsamente pubescentes. Invólucro 5-10 $\times$ 2-3 mm, estreitamente cilíndrico; brácteas involucrais 6-8, lineares, ápice agudo, glabro ou piloso, dorso glabro; eixo da inflorescência plano, alveolado. Flores 40, róseas, ca. 8,5 mm compr., 5-lobuladas, lóbulos 0,5-0,7 mm compr.; anteras ca. $1 \mathrm{~mm}$ compr., inclusas, apêndice do conectivo ca. 0,2 mm compr., oblongo; estilete ca. $7 \mathrm{~mm}$ compr., ramos do estilete ca. $1 \mathrm{~mm}$ compr. Cipselas ca. $3 \mathrm{~mm}$ compr., híspidas entre as costelas; pápus 7-8 $\mathrm{mm}$ compr.

Material selecionado: Carangola, $20^{\circ} 43^{\prime}$ S, $42^{\circ} 29^{\prime} \mathrm{W}$, 1.400 m, 5.VI.1988, L.S. Leoni 2 (RB). Conceição do Mato Dentro, 800 m, 16.VII.1977, G. Martinelli \& A. Távora 2592 (RB). Ituiutaba, 30.IV.1944, A. Macedo 357 (RB).

Espécie pantropical (Nicolson 1980; Pruski 1997). No Brasil, ocorre como ruderal por todas as Regiões Sudeste, Norte e principalmente Nordeste. Fértil de abril a julho.

Emilia sochifolia caracteriza-se pelas flores róseas que geralmente são do mesmo comprimento que o invólucro do capítulo. Nicolson (1980) cita a existência de duas variedades para a espécie, a variedade típica e E. sonchifolia var. javanica (N. Burm.) Mattf., a primeira com distribuição pantropical e a segunda encontrada da Ásia à Oceania.

\section{Erechtites Raf., Fl. Ludov. 65. 1817.}

Ervas anuais ou perenes. Caule ramificado. Lâminas foliares lanceoladas, oblanceoladas, oblongo-lanceoladas, obovadas, ovadas, oblongo-ovadas ou ovado-lanceoladas, ápice agudo ou acuminado, base atenuada, margem denteada, lobada, serreada ou pinatilobada a pinatissectas, sésseis ou subpecioladas, raramente pecioladas. Capítulos heterógamos, disciformes, dispostos em capitulescências corimbiformes. Invólucro cilíndrico; brácteas involucrais 12-14. Flores marginais 1-multisseriadas, pistiladas, às vezes com rudimento de estames; corola longamente filiforme, amarelas, alvacentas ou esverdeadas. Flores centrais perfeitas; corola tubulosa, amarela, alvacentas ou esverdeada. Anteras com base obtusa, auriculadas. Ramos do estilete com ápice truncado, apêndice de tricomas papilosos fusionados, envoltos por uma coroa de tricomas divergentes. Cipselas cilíndricas a obcônicas, 10-costeladas, pilosas ou seríceas; pápus alvacento ou purpúreo, persistente.

Erechtites diferencia-se dos demais gêneros de Senecioneae ocorrentes no Brasil pelos capítulos disciformes e pelas flores marginais possuírem corola filiforme. O gênero possui cinco espécies (Belcher 1956; Nordenstam 2007), as quais foram agrupadas por Belcher (1956) em duas seções, E. sect. Hieraciifoliae 
[E. hieracifolius (L.) Raf. ex DC., E. missionum Malme e E. valerianifolius (Wolf) DC.] e $E$. sect. Goyazenses [E. goyazensis (Gardner) Cabrera e E. ignobilis Baker]. Borges \& Teles (2015c) reportam para o Brasil a ocorrência das cinco espécies do gênero. Apesar de Belcher
(1956) e Hind (1993) citarem a ocorrência de $E$. goyazensis em Minas Gerais, dentre o material que nós examinamos não nos foi possível identificar essa espécie. Portanto, consideramos que em Minas Gerais o gênero está representado apenas por três espécies.

\section{Chave de identificação para as espécies de Erechtites ocorrentes em Minas Gerais}

1. Ervas anuais; invólucro $5-12 \times 3-8 \mathrm{~mm}$, brácteas involucrais $12-14$; corola das flores centrais $8-10$ mm compr.

2. Folhas todas sésseis; folhas apicais com margem irregularmente serreada, denteada ou lobada; invólucro 9-12 × 5-8 mm; pápus alvacento... 3.1. E. hieracifolius

2'. Folhas basais pecioladas, pecíolos $0,7-2 \mathrm{~cm}$ compr., apicais sésseis; folhas apicais com margem pinatilobada a pinatissecta, lobos ou sectos oblongos ou lanceolados, serrados ou dentados; invólucro 5-8 × 3-4 mm; pápus purpúreo. 3.3. E. valerianifolius

1'. Subarbustos perenes; invólucro 18-25 × 9-12 mm, brácteas involucrais 15 ; corola das flores centrais 16-18 mm compr. 3.2. E. ignobilis

3.1 Erechtites hieracifolius (L.) Raf. ex DC., Prodr. 6: 294. 1838. Fig. $1 j$

Ervas eretas, anuais, $0,2-1,5 \mathrm{~m}$ alt. Caule herbáceo, multisulcado, meduloso, densamente folhoso na porção basal, laxamente folhoso na porção apical, esparsamente piloso. Lâmina foliar 2,5-16 × 0,5-3 cm, inteira, lanceolada a oblongo-lanceolada, ápice agudo, margem irregularmente serreada, denteada ou lobada, peninérvea, séssil, glabra a esparsamente pilosa em ambas as faces. Capitulescência laxa a congesta. Capítulos com pedúnculos $2-15 \mathrm{~mm}$ compr., glabros a esparsamente pilosos; bractéolas lanceoladas, 5-8 mm compr., ciliadas. Invólucro 9-12 × 5-8 mm, caliculado; brácteas do calículo 14, lineares, 4-4,5 mm compr., ciliadas; brácteas involucrais $12-14$, lanceoladas a oblongas, ápice agudo, piloso, margem escariosa, 4-nervadas, glabras dorsalmente; eixo da inflorescência plano, alveolado. Flores marginais alvacentas, esverdeadas ou amareladas, multisseriadas, corola ca. $7 \mathrm{~mm}$ compr., 3-5-lobuladas, lóbulos ca. 0,5 mm compr., estilete ca. 7,5 mm compr., ramos do estilete ca. 0,5 $\mathrm{mm}$ compr. Flores centrais alvacentas, esverdeadas ou amareladas, corola tubulosa, $8-8,5 \mathrm{~mm}$ compr., 5-lobulada, lóbulos ca. $1 \mathrm{~mm}$ compr., anteras ca. $1 \mathrm{~mm}$ compr., apêndice do conectivo oblongo, ca. $0,5 \mathrm{~mm}$ compr., estilete ca. $8 \mathrm{~mm}$ compr., ramos do estilete ca. 0,5 mm compr. Cipselas 1-3 mm compr., pilosas; pápus 7-7,5 mm compr., alvacento.

Material selecionado: Diamantina, $18^{\circ} 15^{\prime} 01^{\prime}$ 'S, 4339'08”W, 13.II.2001, J.R. Stehmann et al. 2723
(BHCB). Januária, 15³9'59,5”S, 44³7’58,2”W, 15.V.2002, J.A. Lombardi et al. 4758 (BHCB). Rio Preto, 1.600 m, 21 ${ }^{\circ} 58^{\prime} 31,4$ "S, 435'28,7'W, 9.IV.2007, A.M. Teles et al. 395 (CESJ).

Espécie amplamente distribuída por toda a América tropical, subtropical, África e Ásia (Belcher 1956). Segundo Pruski (1997) a espécie é nativa do Novo Mundo, do Canadá à Argentina, e adventícia na Europa, Índia e China. Hind (1993) citou para o Brasil a ocorrência apenas de E. hieracifolius (L.) Raf. ex DC. var. cacalioides (Fish. ex Spreng.) Griseb. emend. Belcher, que é encontrada nos estados das Regiões Sul, Sudeste, Centro-Oeste, Nordeste (Bahia, Ceará, Pernambuco e Sergipe) e Norte (Acre, Amazonas e Pará). Em Minas Gerais, ocorre em campos rupestres, em canga e ocasionalmente como ruderal em áreas antropizadas. Fértil de outubro a julho.

Erechtites hieracifolius diferencia-se de E. ignobilis, espécie morfologicamente afim, pelo menor comprimento do invólucro, e de $E$. valerianifolius pelas folhas com margem apenas irregularmente serreada, denteada ou lobada e pelo pápus alvacento (versus margem pinatilobada ou pinatissecta e pápus purpúreo).

Nomes vernaculares: capiçoba, caruruamargoso, erva-gorda.

3.2 Erechtites ignobilis Baker, Fl. bras. 6(3): 299. 1884.

Fig. $1 \mathrm{k}$

Subarbustos, perenes, $0,4-0,8 \mathrm{~m}$ alt. Caule multisulcado, meduloso, densamente folhoso na porção basal, laxamente folhoso na porção apical, 
glabro. Folhas basais com lâmina 7-10 × 1,2-2 $\mathrm{cm}$, inteira, obovada a oblanceolada, ápice agudo, margem denteada, dentes esparsos e conspícuos, subpeciolada, glabra em ambas as faces. Folhas apicais gradativamente menores, lâmina inteira, lanceolada, ápice agudo, margem denteada, glabra, sésseis. Capitulescência laxa, composta por 1-3 capítulos. Capítulos com pedúnculos 1,5-11,3 cm compr., glabros; bractéolas linear-lanceoladas, 3,5-6 mm compr., glabras. Invólucro 18-25 × 9-12 $\mathrm{mm}$, caliculado; brácteas do calículo 4, lineares, 5-6,2 mm compr., glabras; brácteas involucrais 15, lanceoladas, ápice agudo, piloso, margem escariosa, 4-5-nervadas, dorso glabro; eixo da inflorescência plano, alveolado. Flores marginais multisseriadas, corola ca. $10 \times 15 \mathrm{~mm}$ compr., 3-5-lobuladas, alvas. Flores centrais com corola 16-18 mm compr., 5-lobulada, alvas. Cipselas 4-5 mm compr., seríceas; pápus $15-25 \mathrm{~mm}$ compr., alvacento.

Material selecionado: Araxá, 2.II.1956, A. Macedo 4229 (RB). Paracatú, 1.000 m, 8.II.1970, H.S. Irwin 26316 (RB). Prata, 21.III.1963, F.M.R. Magalhães 56 (RB).

Segundo Belcher (1956) e Hind (1993) E. ignobilis ocorre no Brasil apenas no Paraná e em Minas Gerais, além de ocorrer no Paraguai. Ao que parece, E. ignobilis trata-se de uma espécie rara nos dois estados. Fértil de fevereiro a abril.

Erechetites ignobilis difere das demais espécies do gênero pelos capítulos com invólucro excepcionalmente maiores $(18-25 \times 9-12 \mathrm{~mm}$ versus 5-12 × 3-8 $\mathrm{mm}$ nas demais espécies).

\subsection{Erechtites valerianifolius (Wolf) DC., Prodr.} 6: 295.1837. Fig. 11-m

Ervas eretas, anuais, até $2 \mathrm{~m}$ alt. Caule herbáceo, multisulcado, meduloso, densamente folhoso por toda a extensão, glabrescente. Folhas basais com lâmina 4-9 × 1,3-3 cm, inteira, ovadolanceolada, ápice agudo, margem irregularmente serreada ou denteada, peninérvea, glabrescente em ambas as faces; pecíolos 0,7-2 cm compr., glabrescentes. Folhas apicais com lâmina 4,5-23 $\times 0,7-11 \mathrm{~cm}$, ovada a oblongo-ovada, ápice agudo, margem pinatilobada a pinatissecta, lobos ou sectos oblongos ou lanceolados, serrados ou dentados, peninérvea, séssil, glabrescente em ambas as faces. Capitulescência congesta. Capítulos com pedúnculos 2-20 mm compr., glabrescentes; bractéolas 2-5 $\mathrm{mm}$ compr., lanceoladas, glabrescentes. Invólucro 5-8 $\times$ 3-4 mm, caliculado; brácteas do calículo 7, 2-3 mm compr., lineares, glabrescentes; brácteas involucrais 12-13, lanceoladas a oblongas, ápice agudo, glabro, margem escariosa, dorso glabro; eixo da inflorescência plano, alveolado. Flores marginais 1-2-seriadas, púrpuras, corola ca. $9 \mathrm{~mm}$ compr., 3-5-lobuladas, lóbulos ca. 0,5 mm compr., estilete ca. $9 \mathrm{~mm}$ compr., ramos do estilete ca. 0,5 mm compr. Flores centrais com corola ca. 10 mm compr., 5-lobulada, lóbulos ca. $1 \mathrm{~mm}$ compr., púrpuras, anteras ca. $1 \mathrm{~mm}$ compr., apêndice do conectivo oblongo, ca. 0,5 mm compr., estilete ca. $9 \mathrm{~mm}$ compr., ramos do estilete ca. $0,5 \mathrm{~mm}$ compr. Cipselas 1-3 mm compr., pilosas; pápus 9-10 mm compr., purpúreo.

Material selecionado: Camanducaia, 22\%42'27'S, 4556'56"W, 31.V.2001, J.A. Lombardi 4377 (BHCB). Carmópolis de Minas, 24.I.2004, L. Echternacht \& T. Dornelas 154 (BHCB). Gouveia, 18²5'35"S, 4341'30"W, 1.346 m, 22.I.2004, R. Mello-Silva et al. 2444 (UEC).

Espécie amplamente distribuída por toda a América tropical e adventícia agressiva na Ásia tropical, ilhas do Pacífico e Norte da Austrália (Belcher 1956; Pruski 1997). No Brasil, ocorre nos estados das Regiões Sul, Sudeste e Nordeste (Bahia e Pernambuco). Em Minas Gerais, ocorre como ruderal em áreas antropizadas e como invasora de culturas. Fértil de setembro a maio.

Espécie facilmente difereciável das congenéricas pela lâmina foliar com margem pinatilobada a pinatissecta e pelo pápus purpúreo. Hind (1993) citou para o Brasil a ocorrência das quatro formas, sendo que destas apenas $E$. valerianifolius f. organensis, E. valerianifolius $\mathrm{f}$. prenanthoides e E. valerianifolius f. valerianifolius ocorreriam em Minas Gerais.

Nomes vernaculares: berdoega, capiçoba, muxoco, caruru-amargoso.

4. Graphistylis B. Nord., Opera Bot. 44: 56. 1978.

Ervas a arbustos perenes. Caule simples a ramificado. Lâminas foliares elípticas a lanceoladas, ápice agudo, acuminado, base obtusa a aguda, margem inteira, serreada ou denticulada, pecioladas. Capítulos heterógamos radiados ou homógamos discoides [G. serrana (Zardini) B.Nord.], dispostos em capitulescências corimbiformes, paniculiformes ou panículadocorimbiformes. Invólucro campanulado, brácteas involucrais 8-13. Flores do raio (3-)5-8, pistiladas, corola liguliforme, amarelas ou alvacentas. Flores do disco 15-28, perfeitas, corola tubulosa. Anteras com base obtusa, auriculadas. Ramos do estilete com ápice truncado, com conspícuo tufo 
de tricomas partindo do centro, circundado por coroa de tricomas curtos, divergentes. Cipselas cilíndricas a obcônicas, 10-costeladas, glabras. Pápus alvacento, persistente.

Graphistylis foi descrito por Nordenstam (1978) para abrigar as espécies de Senecio sect. Dichroa Cabrera. As espécies de Graphistylis são caracteristicas dos campos de altitude, onde ocorrem associadas a populações de Sphagnum
L. e Chusquea Kunth, formando pequenos capões arbustivos.

Todas as nove espécies do gênero são exclusivas das Regiões Sul e Sudeste do Brasil (BFG 2015) e são facilmente reconhecíveis pelo ápice dos ramos do estilete que possuem um conspícuo tufo de tricomas partindo do centro, circundado por uma coroa de tricomas mais curtos. Em Minas Gerais, o gênero está representado por cinco espécies.

\section{Chave de identificação para as espécies de Graphistylis ocorrentes em Minas Gerais}

1. Lâmina foliar com a face abaxial densamente níveo-tomentosa 4.1. G. argyrotricha

1'. Lâmina foliar glabra em ambas as faces ou glabrescente sobre as nervuras na face abaxial ou glabra a hirsuta na face abaxial.

2. Lâmina foliar mais de quatro vezes mais longa que larga.

3. Lâmina foliar lanceolada ou obovada, margem denteada; brácteas involucrais 8; flores do raio 5-7, limbo 4-9 × 1,5-3 $\mathrm{mm}$; flores do disco com corola 4-9 mm compr.

4.2. G. dichroa

3'. Lâmina foliar oblanceolada, margem inteira ou serreada; brácteas involucrais 13; flores do raio 8 , limbo ca. $13 \times 6 \mathrm{~mm}$; corola das flores do disco ca. $10 \mathrm{~mm}$ compr.

4.5. G. riopretensis

2'. Lâmina foliar menos de quatro vezes mais longa que larga.

4. Lâmina foliar normalmente verde concolor ou, menos comumente, com a face adaxial esverdeada e abaxial vinácea, margem inteira a crenada, revoluta; brácteas involucrais 11 .. 4.3. G. itatiaiae

4'. Lâmina foliar conspicuamente discolor, com face adaxial castanho escura e abaxial castanho clara, margem denteada, plana; brácteas involucrais $8-10$ 4.4. G. organensis

4.1 Graphistylis argyrotricha (Dusén) B. Nord., Opera Bot. 44: 58. 1978.

Fig. 1n

Ervas a subarbustos eretos, perenes, rizomatosos, $1,5-2,5 \mathrm{~m}$ alt. Caule multisulcado, fistuloso, áfilo na porção basal, densamente folhoso na porsal apical, glabro. Folhas com lâmina 3-16 × 0,6-4,5 cm, lanceolada a oblongolanceolada, ápice agudo, base atenuada, margem revoluta, serreada, dentes agudos, face adaxial esverdeada, peninérvea, nervuras inconspícuas, glabra, face abaxial densamente níveo-tomentosa, peninérvea, com finas nervuras reticuladas anastomosadas; pecíolos $0,2-3 \mathrm{~cm}$ compr., glabros ou às vezes esparsamente níveo-tomentosos. Capitulescência corimbiforme, congesta. Capítulos heterógamos, radiados; pedúnculos 3-12 mm compr., argênteo-tomentosos; bractéolas 4-7 mm compr., lanceoladas, níveo-tomentosas. Invólucro 6-10 × 4-8 mm, caliculado; brácteas do calículo 4, 4-5 mm compr., lanceoladas, glabras; brácteas involucrais 8 , oblongo-lanceoladas, ápice agudo, piloso, margem escariosa, dorso glabro, eixo da inflorescência plano, alveolado. Flores do raio 5-7, corola amarela, tubo 5-6 mm compr., limbo 8-11 × 3-3,5 mm, 4-nervada, ápice 3-dentado, estilete ca. $9 \mathrm{~mm}$ compr., ramos do estilete ca. $2 \mathrm{~mm}$ compr. Flores do disco 15, corola ca. $9 \mathrm{~mm}$ compr., 5-lobulada, lóbulos da corola ca. $2 \mathrm{~mm}$ compr., anteras ca. 2,5 mm compr., inclusas, apêndice do conectivo ca. $1 \mathrm{~mm}$ compr., oblanceolado; estilete ca. $10 \mathrm{~mm}$ compr., ramos do estilete ca. $2 \mathrm{~mm}$ compr. Cipselas 2,5-3 $\mathrm{mm}$ compr., cilíndricas, glabras; pápus $8-8,5 \mathrm{~mm}$ compr.

Material selecionado: Alagoa, $2.376 \mathrm{~m}, 22^{\circ} 12^{\prime} 14^{\prime \prime}$, $44^{\circ} 46^{\prime} 07^{\prime}$ 'W, 10.XI.2007, P.L. Viana et al. 3261 (BHCB). Itamonte, $2.000 \mathrm{~m}, 22^{\circ} 22^{\prime} 21^{\prime \prime} \mathrm{S}, 44^{\circ} 49^{\prime} 02^{\prime \prime} \mathrm{W}$, 13.III.2007, L.D. Meireles et al. 2808 (BHCB, UEC).

Graphistylis argyrotricha foi considerada por Barroso (1957), Cabrera (1957) e Hind (1993) como sendo endêmica do Maciço do Itatiaia, Rio de Janeiro. No entanto, examinaram-se coletas oriundas de Minas Gerais, nos municípios de Alagoa, Itamonte e Passa Quatro, tratando-se do 
primeiro registro da espécie para Minas Gerais. Ocorre em campos de altitude, de 1.974 a 2.800 m.s.m. Fértil de novembro a maio.

Espécie caracterizada por possuir a face abaxial da lâmina foliar densamente níveotomentosa. Além de G. aryrotricha, somente $G$. toledoi Cabrera, endêmica da Serra da Bocaina no estado de São Paulo, possui lâmina foliar com a face abaxial densamente tomentosa, porém $G$. argyrotricha difere de $G$. toledoi pela lâmina foliar lanceolada a oblongo-lanceolada, níveo-tomentosa e denteada (versus lâmina foliar elíptica, gríseotomentosa e serreada).

\subsection{Graphistylis dichroa (Bong.) D.J.N. Hind, Kew} Bull. 48(2): 285. 1993.

Fig. 1o

Subarbustos eretos, perenes, rizomatosos, 1-3 $\mathrm{m}$ alt. Caule multisulcado, fistuloso, densamente folhoso na porção basal, laxamente folhoso na porção apical, glabro a tomentoso. Folhas com lâmina 3-22 × 0,5-5,5 cm, lanceolada ou obovada, ápice agudo, base atenuada, margem revoluta, denteada, dentes largos a estreitos, ciliada, face adaxial esverdeada, peninérvea, com finas nervuras reticuladas anastomosadas, glabra, face abaxial variando de vinácea a verde, peninérvea, sem nervuras reticuladas anastomosadas, nervuras primárias e secundárias conspicuamente marcadas, hirsuta a glabra nas nervuras; pecíolos $0,3-5 \mathrm{~cm}$ compr., glabros ou hirsutos lateralmente na base. Capitulescência paniculado-corimbiforme, laxa. Capítulos heterógamos, radiados, pedunculados; pedúnculos 2-25 mm compr., bracteolados, hirsutos; bractéolas lanceoladas, 4-5 mm compr., hirsutas. Invólucro 7-9 × 3-9 mm, caliculado; brácteas do calículo 2-5, 3-5 mm compr., lanceoladas, ciliadas; brácteas involucrais 8 , oblongo-lanceoladas, ápice agudo, glabro ou piloso, margem escariosa, glabras dorsalmente; eixo da inflorescência côncavo a convexo, alveolado. Flores do raio 5-7, pistiladas, corola amarela, tubo da corola $0,5-3 \mathrm{~mm}$ compr., limbo 4-9 × 1,5-3 mm, 4-nervada, ápice 3-dentado, estilete $6-6,5 \mathrm{~mm}$ compr., ramos do estilete ca. 1,5 $\mathrm{mm}$ compr. Flores do disco 17-21, corola 4-9 mm compr., 5-lobulada, lóbulos 1-2 mm compr., anteras 2-2,5 mm compr., inclusas, apêndice do conectivo 0,7-1,2 mm compr., deltóide, base obtusa; estilete $3-8 \mathrm{~mm}$ compr., ramos do estilete $1,5-1,7 \mathrm{~mm}$ compr. Cipselas 1-2 mm compr., cilíndricas a obcônicas, glabras; pápus 4-8 $\mathrm{mm}$ compr.

Material selecionado: Catas Altas, 5.IV.2007, A.M. Teles et al. 381 (BHCB). Passa Quatro, 2.500-2.547 m, $22^{\circ} 25^{\prime} 25,5^{\prime \prime} \mathrm{S}, 44^{\circ} 51^{\prime} 55,2^{\prime \prime} \mathrm{W}, 22 . \mathrm{VI} .2007$, L.D. Meireles et al. 3187 (BHCB, UEC). Rio Preto, 21 $57^{\prime} 50,9^{\prime \prime}$, $43^{\circ} 52^{\prime} 45,7$ 'W, 10.IV.2007, A.M. Teles et al. 400 (BHCB).

Hind (1993) considerou a espécie como endêmica de Minas Gerais, no entanto, examinouse materiais provenientes do Rio de Janeiro, São Paulo e Santa Catarina [tratados por Cabrera (1957) e Cabrera \& Klein (1975) como S. oreophilus Dusén]. Em Minas Gerais ocorre em campos de altitude ou em bordas de pequenos capões nebulares em altitudes que variam de 1.700 a 2.790 m.s.m. Fértil de fevereiro a julho.

Graphistylis dichroa é caracterizada por apresentar lâminas foliares lanceoladas ou obovada, com ápice agudo, margem denteada, revoluta, e com nervuras conspícuas na face abaxial.

\subsection{Graphistylis itatiaiae (Dusén) B. Nord., Opera} Bot. 44: 58. 1978.

Fig. 1p

Ervas a arbustos eretos, perenes, rizomatosos, até $2 \mathrm{~m}$ alt. Caule multisulcado, fistuloso, densamente folhoso na porção basal, laxamente folhoso na porção apical, glabro a tomentoso. Folhas com lâmina 2,5-15,5 × 1-5,5 cm, elíptica a obovada, ápice agudo, base atenuada, margem inteira a crenada, ciliada, revoluta, com finas nervuras reticuladas anastomosadas em ambas as faces, face adaxial esverdeada, peninérvea, glabra a esparsamente hirsuta, face abaxial variando de verde a vinácea, peninérvea, glabra a hirsuta; pecíolos 0,5-2 cm compr., tomentosos. Capitulescência paniculado-corimbiforme, laxa. Capítulos heterógamos, radiados; pedúnculos 4-20 mm compr., tomentosos; bractéolas 4-5 mm compr., lanceoladas, hirsutas. Invólucro 10-11 × 6-7 mm, caliculado; brácteas do calículo 6, lanceoladas, ciliadas; brácteas involucrais 11 , oblongo-lanceoladas, ápice agudo, piloso, margem escariosa, dorso glabro; eixo da inflorescência convexo, alveolado. Flores do raio 5-8, corola amarela, tubo ca. $5 \mathrm{~mm}$ compr., limbo $6-8,5 \times$ 2,5-4 mm, 4-nervada, ápice 3-dentado, estilete 8-9 mm compr., ramos do estilete 1-2 mm compr. Flores do disco $22-28$, corola $8-8,5 \mathrm{~mm}$ compr., 5-lobulada, lóbulos 1,5-2 mm compr., anteras ca. 2 $\mathrm{mm}$ compr., inclusas, apêndice do conectivo $0,5-1$ $\mathrm{mm}$ compr., oblongo; estilete 9-10 $\mathrm{mm}$ compr. Cipselas 2-2,5 mm compr., cilíndricas, glabras; pápus 6-7 $\mathrm{mm}$ compr.

Material selecionado: Alto Caparaó, 23.XI.2006, A.M.

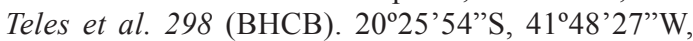
2.IX.1996, V.C. Souza et al. 12187 (ESA). Passa Quatro, $2.481 \mathrm{~m}, 22^{\circ} 25^{\prime} 58^{\prime \prime}$ 'S, 445'ㄹ'20,6”'W, 11.VI.2005, L.D. Meireles et al. 1833 (BHCB, UEC). 
Cabrera (1957) e Hind (1993) consideraram a espécie como ocorrente apenas em Minas Gerais e Rio de Janeio, porém examinou-se material proveniente do município de Queluz, São Paulo. Em Minas Gerais ocorre em campos de altitude (1.650 a 2.890 m.s.m.). Fértil de abril a novembro.

Graphistylys itatiaiae é uma das espécies mais variáveis morfologicamente, e tem $G$. organensis como espécie morfologicamente afim, porém difere desta pelas folhas com lâmina verde concolor ou, quando muito, verde adaxialmente e vinácea abaxialmente (versus castanho escura adaxialmente e castanho clara abaxialmente), pela margem inteira a crenada e revoluta (versus margem denteada e plana) e pelo número de brácteas involucrais que são em número de 11 (versus 8-10).

4.4 Graphistylis organensis (Casar.) B. Nord., Opera Bot. 44: 58. 1978.

Fig. 1q

Ervas a arbustos eretos, perenes, rizomatosos, até $2,5 \mathrm{~m}$ alt. Caule multisulcado, fistuloso, folhoso por toda a extensão, tomentoso a glabro. Folhas com lâmina 10-22 × 3-10 cm, obovada a oblanceolada, ápice agudo, base atenuada, margem denteada, ciliada, plana, conspicuamente discolor, com face adaxial castanho escura e abaxial castanho clara, peninérvea, com finas nervuras reticuladas na face abaxial, glabra em ambas as faces ou glabrescente sobre as nervuras na face abaxial; pecíolos 2-3 cm compr., glabros. Capitulescência paniculado-corimbiforme, laxa. Capítulos heterógamos, radiados; pedúnculos 10$15 \mathrm{~mm}$ compr., glanduloso-pubescentes; bractéolas lanceoladas, 5-6 mm compr., ciliadas. Invólucro ca. $10 \times 7-9 \mathrm{~mm}$, caliculado; brácteas do calículo 5, lineares, 5-6 mm compr., ciliadas; brácteas involucrais 8-10, lanceoladas, ápice agudo, piloso, margem escariosa, glabras dorsalmente; eixo da inflorescência convexo, alveolado. Flores do raio 3-5, corola amarela, tubo ca. $6 \mathrm{~mm}$ compr., limbo 7-10 × 3-3,5 mm, 8-9-nervada, ápice 3-dentado, estilete ca. $10 \mathrm{~mm}$ compr., ramos do estilete ca. 2 $\mathrm{mm}$ compr. Flores do disco 17-25, corola ca. 8 mm compr., 5-lobulada, lóbulos 1,5-2 mm compr., anteras ca. $2 \mathrm{~mm}$ compr., inclusas, apêndice do conectivo ca. $1 \mathrm{~mm}$ compr., oblongo; estilete ca. $11 \mathrm{~mm}$ compr., ramos do estilete ca. $2 \mathrm{~mm}$ compr. Cipselas 2,5-4 mm compr., cilíndricas, glabras; pápus 6-8 $\mathrm{mm}$ compr.

Material selecionado: Alto Caparaó, $2.650 \mathrm{~m}$, 17.IX.1988, L. Krieger et al. FPNC 268 (CESJ). Passa

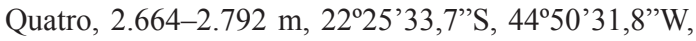

22.VI.2007, L.D. Meireles et al. 3196 (BHCB, UEC). São Gonçalo do Rio Preto, $1.831 \mathrm{~m}, 18^{\circ} 12^{\prime} 28^{\prime \prime}$, $43^{\circ} 18^{\prime} 38^{\prime \prime} \mathrm{W}, 23$. V.2007, V.T. Giorni et al. 20 (BHCB).

Ocorre em Minas Gerais, Espírito Santo, São Paulo e Santa Catarina, em campos de altitude localizados em altitudes superiores a 1.970 m.s.m. Fértil de abril a setembro.

Graphistylis organensis caracteriza-se pelas lâminas foliares conspicuamente discolores, peninérveas e com margem plana. Cabrera (1957) descreveu G. organensis f. albiflora, endêmica da Serra dos Órgãos, que difere da forma típica pelas flores radiais alvacentas.

4.5 Graphistylis riopretensis A. Teles \& B. Nord., Comp. Newsl. 46: 76-82. $2008 . \quad$ Fig. 1r-s

Arbustos eretos, perenes, rizomatosos, ca. 1,5 m alt. Caule multisulcado, meduloso, folhoso por toda a extensão, glabro. Folhas basais com lâmina 8-12 ×2-3 cm, oblanceolada, ápice agudo, base obtusa, margem serreada, dentes pequenos, esparsos, plana, concolor, verde, peninérvea, glabra na face adaxial, laxamente hirsuta na face abaxial; pecíolos $0,5-0,7 \mathrm{~cm}$ compr., laxamente hirsutos. Folhas apicais com lâmina $3-5 \times 0,7-0,8 \mathrm{~cm}$, oblanceolada, ápice agudo, base truncada, margem inteira ou serreada, dentes pequenos, esparsos, plana, concolor, verde, peninérvea, glabra na face adaxial, laxamente hirsuta na face abaxial, séssil. Capitulescência paniculiforme, ampla. Capítulos heterógamos, radiados; pedúnculos 2,5-4 cm compr., hirsutos; bractéolas 3-4 mm compr., lanceoladas, hirsutas. Invólucro 9-11 × 7-9 mm, caliculado; brácteas do calículo 5, 3-4,5 mm compr., lanceoladas, ciliadas; brácteas involucrais 13, oblongas, ápice agudo, vináceo, penicelado, margem escariosa, hialina, dorso glabro; eixo da inflorescência plano, alveolado. Flores do raio 8, corola amarela, tubo ca. 5,5 mm compr., limbo ca. $13 \times 6 \mathrm{~mm}, 6$-nervada, ápice 3-dentado, estilete ca. $9 \mathrm{~mm}$ compr., ramos do estilete ca. $4 \mathrm{~mm}$ compr. Flores do disco 20, corola ca. $10 \mathrm{~mm}$ compr., 5-lobulada, lóbulos 1,5-2 mm compr., anteras ca. 2,5 mm compr., inclusas, apêndice do conectivo ca. 0,5 mm compr., deltóide; estilete ca. 11,5 mm compr., ramos do estilete ca. 2,5 mm compr. Cipselas ca. 2,5 mm compr., cilíndricas, glabras; pápus $8-9 \mathrm{~mm}$ compr.

Material examinado: São Gonçalo do Rio Preto, Parque Estadual do Rio Preto, Pico Dois Irmãos, 10.VIII.2004, P.L. Viana \& N.O.F. Mota 1825 (BHCB, holótipo).

Espécie conhecida até o momento unicamente para o Pico Dois Irmãos, no Parque 
Estadual do Rio Preto, município de São Gonçalo de Rio Preto, Minas Gerais. Como as demais espécies do gênero, G. riopretensis ocorre em campos de altitude, em altitudes que variam de 1.800 a 1.830 m.s.m. Fértil em agosto.

Graphistylis riopretensis tem como espécie morfologicamente afim $G$. dichroa, porém difere pelas lâminas foliares oblanceoladas, com margem serreada (versus lâminas foliares lanceoladas a obovadas e com margem denteada) e pelas dimensões do limbo das flores do raio, maiores em G. riopretensis (ca. $13 \times 6 \mathrm{~mm}$ ) que em $G$. dichroa (4-9 × 1,5-3 mm).

5. Hoehnephytum Cabrera, Brittonia 7: 53. 1950. Hoehnephytum é endêmico do Brasil, com duas espécies distribuídas pelas Regiões Nordeste (Bahia), Centro-Oeste (Goiás) e Sudeste (Minas Gerais e São Paulo) (BFG 2015). O gênero foi segregado de Senecio s.l. por Cabrera (1950), com base no ápice dos ramos do estilete, que em Hoehnephytum é arredondado e pubérulo apenas dorsalmente, diferentemente de Senecio s.s., que possui o ápice dos ramos do estilete truncado e envolto por uma coroa de tricomas. Em Minas Gerais está representado por uma espécie.

\subsection{Hoehnephytum trixoides (Gardner) Cabrera,} Brittonia 7: 53. 1950. Fig. 2a-c

Subarbustos a arbustos eretos, perenes, 0,4-2 $\mathrm{m}$ alt. Caule simples ou ramificado, multisulcado, meduloso, densamente folhoso por toda a extensão, glabro. Folhas com lâmina 0,8-5,5 × 0,4-3 cm, inteira, ovada a elíptica, ápice agudo a obtuso, margem inteira, base aguda, obtusa ou atenuada, triplinérvea a obscuramente peninérvea, glabra em ambas as faces, séssil a peciolada; pecíolos 1-8 mm compr., glabros. Capitulescência corimbiforme. Capítulos homógamos, discoides; pedúnculos 1-12 mm compr., glabros; bractéolas lanceoladas, 2-5 $\mathrm{mm}$ compr., glabras. Invólucro 6-10 × 3-5 mm, campanulado, ecaliculado; brácteas involucrais 5 , oblongas, ápice agudo, piloso, margem escariosa, dorso glabro; eixo da inflorescência plano, fimbriado. Flores 5, andróginas, corola tubulosa, alvacenta a esverdeada, 7-9,5 mm compr., 5-lobulada, lóbulos ca. $3 \mathrm{~mm}$ compr., anteras 2-2,5 mm compr., exsertas, base obtusa, apêndice do conectivo ca. 0,5 mm compr., oblongo; estilete 6,5-11 mm compr., ramos do estilete ca. $2 \mathrm{~mm}$ compr., ápice arredondado, pubérulo apenas dorsalmente. Cipselas 1,5-3,5 mm compr., obcônicas, costeladas, hirsutas; pápus 5-8 $\mathrm{mm}$ compr., alvacento, persistente.
Material selecionado: Moeda, $1.560 \mathrm{~m}, 20^{\circ} 20^{\prime} 9,4$ 'S, 4356'17,1"W, 26.IV.2007, F.F. Carmo \& R. Alves 444 (BHCB). Rio Vermelho, 1806'28'S, 4302'20'W, 1.450 m, 10.I.2006, P.L. Viana et al. 2413 (BHCB). Santana do Riacho, 20.X.2006, A.M. Teles 275 (BHCB).

Ocorre em Goiás, Bahia, Minas Gerais, São Paulo e no Distrito Federal, em campos rupestres com afloramentos quartzíticos ou graníticos, campo cerrado, campo limpo ou ainda crescendo sobre canga, de 800 a 1.600 m.s.m. Fértil de maio a janeiro.

Hind (1993) citou a ocorrência de $H$. imbricatum (Gardner) Cabrera e H. trixoides em Minas Gerais. No entanto, Borges \& Teles (2015e) consideram H. imbricatum sinônimo de H. trixoides.

6. Pentacalia Cass., Dict. Sc. Nat. 48: 461. 1827. O gênero Pentacalia foi revalidado por Robinson \& Cuatrecasas (1978), porém incluído na sinonímia de Senecio (s.l.) por alguns autores como Barkley (1985). É um gênero americano com grande concentração de espécies especialmente nos Andes, porém está distribuído desde a América do Sul à América do Norte (México) (Nordenstam 2007). Possui cerca de 200 espécies que são caracterizadas principalmente pelas folhas conspicuamente coriáceas e pelo hábito escandente ou epifítico (Nordenstam 2007). No Brasil o gênero está representado por duas espécies (BFG 2015), sendo que em Minas Gerais ocorre apenas uma.

\subsection{Pentacalia desiderabilis (Vell.) Cuatrec.,} Phytologia 52: 164. 1982. Fig. 2d-e

Arbustos escandentes até $20 \mathrm{~m}$ alt. Caule multisulcado, meduloso, laxamente folhoso por toda a extensão, glabrescente. Folhas com lâmina 2-9 × 0,7-5,5 cm, elíptica a ovada, ápice acuminado, base obtusa a aguda, margem inteira, glabra em ambas as faces; pecíolos 0,4-2,5 cm compr., glabrescentes. Capitulescência tirsiforme a paniculado-corimbiforme. Capítulos heterógamos, radiados; pedúnculos 2-13 $\mathrm{mm}$ compr., glabros ou laxamente lanuginosos; bractéolas 2-3 mm compr., lanceoladas, glabras ou laxamente lanuginosas. Invólucro 5-19 × 4-10 mm, campanulado, caliculado; brácteas 3-6, 1,5-4 mm compr., lanceoladas; brácteas involucrais 8 , oblongas, ápice agudo, piloso, margem escariosa, dorso glabro; eixo da inflorescência plano a levemente convexo, alveolado. Flores do raio 5, pistiladas, corola liguliforme, amarela, tubo 3,5-4 mm compr., limbo 4-4,5 × 1-1,2 mm, 4-nervada, ápice 3-dentado, estilete 6,5-7 mm compr., ramos 
do estilete ca. $1 \mathrm{~mm}$ compr. Flores do disco 16, perfeitas, corola tubulosa, ca. $5 \mathrm{~mm}$ compr., 5-lobulada, lóbulos ca. $1 \mathrm{~mm}$ compr., anteras ca. $2 \mathrm{~mm}$ compr., exsertas, base sagitada, apêndice do conectivo ca. $0,2 \mathrm{~mm}$ compr., oblongo; estilete ca. $6 \mathrm{~mm}$ compr., ramos do estilete ca. $1 \mathrm{~mm}$ compr., ápice rômbico, envolto por uma coroa de tricomas divergentes. Cipselas 1,2-1,5 mm compr., obcônicas, 5-costeladas, glabras; pápus 3-9 mm compr., alvacento, persistente.
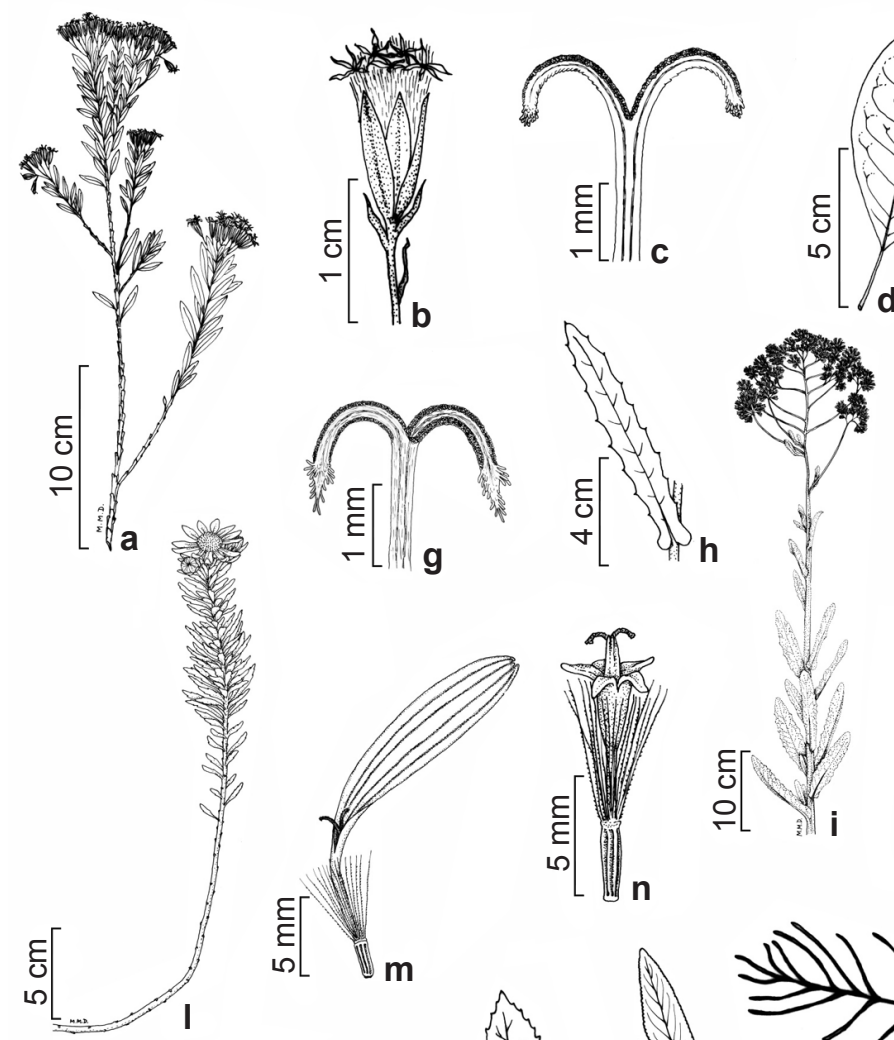

d
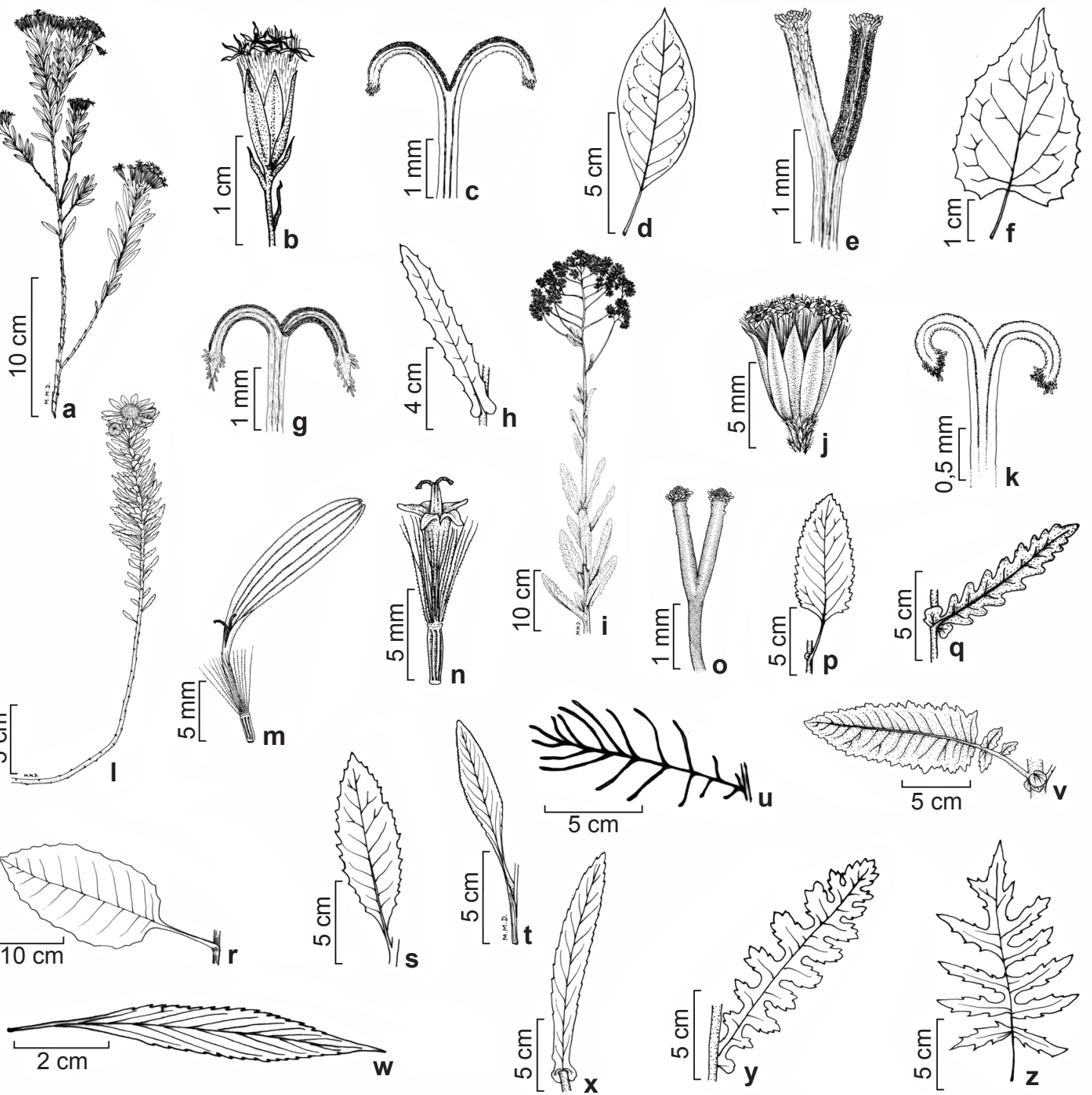

Figura 2 - a-c. Hoehnephytum trixoides - a. ramo florido; b. capítulo; c. ramos do estilete. d-e. Pentacalia desiderabilis d. folha; e. ramos do estilete. f-g. Pseudogynoxys cabrerae - f. folha; g. ramos do estilete. h. Senecio adamantinus - folha. i-k. Senecio albus - i. hábito; j. capítulo; k. ramos do estilete. 1-o. Senecio altimonatnus - 1. hábito; m. flor do raio; $n$. flor do disco; o. ramos do estilete. p. Senecio claussenii - folha. q. Senecio colpodes - folha. r. Senecio grandis - folha. s. Senecio hatschbachii - folha. t. Senecio icoglossus - folha. u. Senecio leptoschizus - folha. v. Senecio macrotis - folha. w. Senecio nemoralis - folha. x. Senecio oleosus - folha. y. Senecio pseudostigophlebius - folha. z. Senecio stigophlebius - folha.

Figure 2 - a-c. Hoehnephytum trixoides - a. flowering branch; b. capitula; c. style branches. d-e. Pentacalia desiderabilis - d. leaf; e. style branches. f-g. Pseudogynoxys cabrerae - f. leaf; g. style branches. h. Senecio adamantinus - leaf. i-k. Senecio albus - i. habit; j. capitula; k. style branches. 1-o. Senecio altimonatnus - 1. habit; m. ray floret; $n$. disc floret; o. style branches. p. Senecio claussenii- leaf. q. Senecio colpodes - leaf. r. Senecio grandis - leaf. s. Senecio hatschbachii-leaf. t. Senecio icoglossus - leaf. u. Senecio leptoschizus - leaf. v. Senecio macrotis - leaf. w. Senecio nemoralis - leaf. x. Senecio oleosus - leaf. y. Senecio pseudostigophlebius - leaf. z. Senecio stigophlebius - leaf. 
Material examinado: Lima Duarte, $1.650 \mathrm{~m}, 21^{\circ} 42^{\prime} 76$ 'S, 4353'83'W, 11.VIII.2005, R.C. Forzza et al. 4148 (BHCB, RB). Ouro Preto, 20¹2'35'S, 4334'27,5”W, 1.904 m, 11.IX.2007, F.F. Carmo 1045, 1072 (BHCB).

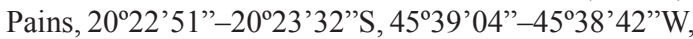
700-750 m, 8.IV.2004, P.H. Melo \& Leal 1144 (BHCB).

Ocorre em todos os estados das Regiões Sul e Sudeste do Brasil (Hind 1993), além da Bahia (Teles \& Stehmann 2008). Em Minas Gerais, ocorre em bordas de capões de mata sobre campos rupestres, em bordas de matas de altitude e em florestas ombrófilas mistas, em altitudes entre 700 e 2.220 m.s.m. Fértil de junho a setembro.

Pentacalia desiderabilis é facilmente reconhecível por ser uma das poucas espécies de Senecioneae nativas do Brasil com hábito escandente. As outras espécies ocorrentes no Brasil com esse hábito de crescimento são: Dendrophorbium pellucidinerve (ocasionalmente escandente), Pentacalia tropicalis (Cabrera) C.Jeffrey, Pseudogynoxys cabrerae H.Rob. \& Cuatrec., $P$. chenopodioides (Kunth) Cabrera e $P$. lobata Pruski. Pentacalia desiderabilis difere da primeira pelas folhas com margem inteira, difere da segunda pelas flores do raio amarelas (versus flores do raio alvacentas), e difere das três espécies de Pseudogynoxys pelas flores do raio amarelas (versus alaranjadas a avermelhadas).

\section{Pseudogynoxys (Greenm.) Cabrera, Brittonia 7: 54. 1950.}

Pseudogynoxys é um dos gêneros de Senecioneae com ocorrência restrita ao Novo Mundo (Hind 1992). Foi originalmente descrito por Greenman (1902) como um subgênero de Senecio, mas foi elevado à categoria genérica por Cabrera (1950) por apresentar o ápice dos ramos do estilete com características bem distintas das demais espécies de Senecio s.s. É um gênero cujas espécies chamam a atenção não apenas pelo hábito escandente, mas também pela beleza das cores dos capítulos, que apresentam flores do raio alaranjadas tendendo ao vermelho com o envelhecimento do capítulo. Robinson \& Cuatrecasas (1977) citaram 12 espécies, mas atualmente o gênero consta de 13 espécies (Pruski 1996; Nordenstam 2007). Pseudogynoxys está representado no Brasil por três espécies (BFG 2015), sendo que em Minas Gerais ocorre apenas uma.

7.1 Pseudogynoxys cabrerae H. Rob. \& Cuatrec., Phytologia 36: 182. $1977 . \quad$ Fig. 2f-g

Subarbustos a arbustos escandentes, perenes. Caule ramificado, multisulcado, meduloso, pubescente. Folhas com lâmina 3,8-8,5 × 3-4 cm, ovada, ápice agudo, curtamente acuminado, base cordada, margem serreada, peninérvea, ambas as faces pubescentes; pecíolos 1-3,5 cm compr., pubescentes. Capitulescência corimbiforme, terminal, laxa. Capítulos heterógamos, radiados; pedúnculos 4,5-10 cm compr., pubescentes; bractéolas 5-6 $\mathrm{mm}$ compr., lanceoladas, pubescentes. Invólucro $1-20 \times 1,5-2,5 \mathrm{~cm}$, campanulado, caliculado; brácteas do calículo 20 30, 5-6 mm compr., lineares a linear-lanceoladas, pubescentes; brácteas involucrais 25-30, lanceoladas, ápice longo-atenuado, piloso, margem escariosa, dorso pubescente; receptáculo plano a convexo, glabro. Flores do raio 12-18, pistiladas, corola liguliforme, alaranjada a avermelhada, tubo da corola ca. $8 \mathrm{~mm}$ compr., limbo 13-15 $\times$ 3-6 mm, 6-10-nervada, ápice 3-dentado. Flores do disco numerosas, perfeitas, corola tubulosa, alaranjada, 11-14 mm compr., 5-lobulada, lóbulos 2-2,5 mm compr., anteras com base obtusa, apêndice do conectivo lanceolado; estilete ca. $8 \mathrm{~mm}$ compr., ramos do estilete com ápice longamente acuminado, com tricomas fusionados. Cipselas ca. $3 \mathrm{~mm}$ compr., cilíndricas, 10-costeladas, densamente pubescentes. Pápus 10-12 mm compr., alvacento, persistente.

Material selecionado: Serra do Cipó, 20.V.1997, I. Castellois 848 (PAMG). Belo Horizonte, 20.XII.1996, R.S. Oliveira LAS 109 (BHCB). Santa Rita do Sapucaí, 15.III.1996, M. Brandão 24830 (PAMG).

Ocorre na Argentina, Paraguai e Brasil (Bahia, Goiás, Mato Grosso do Sul, Minas Gerais, Paraná, Rio de Janeiro, Santa Catarina e São Paulo). No Brasil, é encontrada como cultivada e subespontânea em bordas de florestas. Em Minas Gerais, a espécie é cultivada como ornamental em jardins externos e ocasionalmente encontrada como subespontânea. Fértil de outubro a maio.

Pseudogynoxys cabrerae tem como espécie afim P. chenopodioides (H.B.K.) Cabrera, porém difere pelo caule, folhas e brácteas involucrais pubescentes, enquanto $P$. chenopodioides apresenta esses órgãos glabros.

\section{Senecio L., Sp. Pl. 2: 866. 1753.}

Ervas a arbustos, eretos, prostrados ou decumbentes, anuais ou perenes. Caule simples ou ramificado. Lâminas foliares com formas variadas, ápice agudo a obtuso, base variável na forma, margem inteira, crenada, serreada, denteada, lobada ou variavelmente sectada, peninérveas ou uninérveas, sésseis ou pecioladas, pecíolos cilíndricos, algumas vezes invaginantes, 
canaliculados ou alados. Capítulos homógamos, discoides, ou heterógamos, radiados, solitários ou em capitulescências terminais de tipos diversos. Invólucro campanulado, caliculado ou ecaliculado; brácteas involucrais 7-24. Capítulos discoides com flores 8-70, perfeitas, corola tubulosa, amarela, lilás ou alvacenta. Capítulos radiados com flores do raio 2-21, pistiladas, corola liguliforme, normalmente amarela, algumas vezes lilás ou raramente alvacenta; flores do disco 6-70, andróginas, corola tubulosa, amarela ou alvacenta. Anteras com base obtusa ou levemente aguda. Ramos do estilete com ápice truncado, envolto por uma coroa de tricomas divergentes. Cipselas cilíndricas a obcônicas, 5-10-costeladas, glabras, seríceo-pubescentes, papilosas ou hirsutas. Pápus alvacento, caduco ou persistente.

Senecio é o décimo maior gênero de plantas vasculares (Frodin 2004), com aproximadamente 1.250 espécies (Bremer 1994; Nordenstam et al. 2009). O gênero foi tradicionalmente tratado por alguns autores (e.g., Baker 1884; Cabrera 1950, 1957, 1974, 1978; Barkley 1985), com base em similaridades morfológicas, com uma ampla circunscrição, sendo divido em seções e compreendendo mais de 3.000 espécies (Jeffrey et al. 1977; Nordenstam 2007). No entanto, estudos posteriores (e.g., Vincent \& Gentliffe 1992; Vincent 1996; Pelser et al. 2007) demonstraram ser esse arranjo artificial e que muitas das espécies tratadas como Senecio s.l. são filogeneticamente mais relacionadas com espécies de outros gêneros de Senecioneae (Pelser et al. 2007). Com isso, o gênero nos últimos anos tem tido a sua circunscrição completamente modificada com a segregação de novos gêneros a partir de Senecio s.l. [e.g., Graphistilys (Nordenstam 1978), Hoehnephytum (Cabrera 1950), Pentacalia (Robinson \& Cuatrecasas 1978), Pseudogynoxys (Cabrera 1950), dentre outros]. Pelser et al. (2007) demonstraram, a partir de análise filogenética utilizando marcadores moleculares, que muito desses gêneros são entidades monofiléticas e que muitos outros grupos infragenéricos que hoje são tratados como seções deverão ser segregados de Senecio s.l..

Senecio é cosmopolita, com maior concentração de espécies na América do Sul (Andes) e sul da África (Nordenstam et al. 2009). No Brasil, está representado por 60 espécies encontradas especialmente em áreas montanhosas das Regiões Sul e Sudeste (BFG 2015). Em Minas Gerais, está representado por 26 espécies nativas, das quais oito são endêmicas e duas cultivadas ( $S$. flaccidus Less. e S. tamoides DC.).

\section{Chave de identificação para as espécies de Senecio ocorrentes em Minas Gerais}

1. Folhas basais distintamente pecioladas.

2. Capítulos radiados.

3. Folhas basais pecioladas, sem aurículas na base do pecíolo, folhas apicais sésseis; flores do raio lilases.

4. Folhas basais com lâmina pinatissecta....................................8.10. S. erisithalifolius

4'. Folhas basais com lâmina inteira 8.14. S. icoglossus

3'. Folhas basais e apicais pecioladas, folhas basais auriculadas na base do pecíolo; flores do raio amarelas.

5. Lâmina foliar inteira, ovada, margem crenado-denteada, densamente albo-tomentosa em ambas as faces; pecíolos com aurículas reniformes; flores do disco 70; cipselas seríceopubescentes 8.6. S. claussenii

5'. Lâmina foliar lirado-pinatissecta, elíptica ou obovado-elíptica, margem irregularmente denteada, glabra ou lanuginosa na face adaxial, densamente albo-tomentosa na face abaxial; pecíolos com aurículas semi-circulares; flores do disco 15-20; cipselas glabras.

8.25. S. stigophlebius

2'. Capítulos discoides.

6. Lâmina foliar 30-60 × 15-25 cm, inteira, ovado-oblonga, glabrescente na face adaxial, densamente albo-tomentosa a purpúreo-tomentosa na face abaxial; pecíolos 10-17 cm compr., canaliculados a estreitamente alados; cipselas glabras 8.12. S. grandis

6'. Lâmina foliar (3-)4,7-26 × (1,1-)3,2-13,5 cm, lirado-pinatissecta ou inteira, neste caso, ovado-elíptica, laxamente lanosa na face adaxial e densamente albo-tomentosa na face abaxial 
ou densamente albo-tomentosa em ambas as faces; pecíolos $0,8-8 \mathrm{~cm}$ compr., cilíndricos; cipselas seríceo-pubescentes ou papilosas.

7. Lâmina foliar discolor, lirado-pinatissecta, laxamente lanosa na face adaxial, densamente albo-tomentosa na face abaxial; pecíolos com um par de aurículas reniformes na base; cipselas papilosas 8.18. S. macrotis

7'. Lâmina foliar concolor, inteira, ovado-elíptica, densamente albo-tomentosa em ambas as faces; pecíolos sem aurículas; cipselas seríceo-pubescentes

8.13. S. hatschbachii

1'. Todas as folhas sésseis.

8. Todas as folhas com lâmina inteira, margem inteira, crenado-denteada, crenado-lobada, denteada, lobada ou serreada completamente ou apenas na metade superior da lâmina.

9. Capítulos discoides.

10. Caule pubescente, flores $40-70$.

11. Lâmina foliar pubescente na face abaxial; flores $40-50$ 8.23. S. pohlii

11'. Lâmina foliar tomentosa na face abaxial; flores 70 8.9. S. emiliopsis

10'. Caule densamente albo-tomentoso-aracnoideo ou densamente lanuginoso. Flores 9-35.

12. Invólucro $8-10 \times 7-9 \mathrm{~mm}$; brácteas involucrais 13 , densamente lanuginosas no dorso; flores 35; cipselas 2,5-3,5 mm compr., papilosas nas costelas

8.11 S. gertii

12'. Invólucro $5-7 \times 3-4 \mathrm{~mm}$; brácteas involucrais 7-8, glanduloso-pontuadas e glabrescentes no dorso; flores 9-14; cipselas 1,5-2 mm compr., glabras

8.2. S. albus

9'. Capítulos radiados.

13. Brácteas involucrais $7-15$.

14. Caule densamente folhoso na porção basal; flores do disco 6-20, raro 40.

15. Brácteas involucrais 7-8; flores do raio 2-3; flores do disco 6-9.

8.1. S. adamantinus

15'. Brácteas involucrais 10-15; flores do raio 6-8; flores do disco 18-40.

16. Caule hirsuto-glanduloso; lâmina foliar hirsuto-glandulosa na face adaxial e densamente albo-tomentosa na face abaxial; flores do disco 18-20; cipselas glabras

8.7. S. colpodes

16'. Caule densamente albo-lanoso; lâmina foliar albo-lanosa em ambas as faces; flores do disco 40; cipselas papilosas

8.8. S. dumetorum

14'. Caule folhoso por toda a extensão ou esparsamente folhoso a áfilo na porção basal; flores do disco 40-50.

17. Caule folhoso por toda a extensão; lâmina foliar com margem serreada ou denteada, plana, peninérvea.

18. Caule glabro; lâmina foliar lanceolada; flores do raio 7-8; cipselas hirsutas entre as costelas

8.19. S. nemoralis

18'. Caule gríseo-lanoso; lâmina foliar oblanceolada; flores do raio 10-15; cipselas glabras. 8.5. S. caparaoensis

17'. Caule esparsamente folhoso a áfilo na porção basal; lâmina foliar com margem serreada na metade distal, revoluta, uninérvea. 8.3. S. altimontanus

13'. Brácteas involucrais 20-21.

19. Caule pubescente-glanduloso; lâmina foliar pubescente-glandulosa em ambas as faces; invólucro ca. $10 \times 8-12 \mathrm{~mm}$; flores do raio 15-21; flores do disco 60 . 8.20. S. oleosus

19'. Caule laxamente lanuginoso; lâmina foliar laxamente lanuginosa na face adaxial e densamente lanuginosa na face abaxial; invólucro 6-9 × 4-8 $\mathrm{mm}$; flores do raio 10-12; flores do disco 50 8.15. S. lanifer 
8'. Folhas apicais com lâmina inteira e basais com lâmina pinatissecta ou todas as folhas com lâmina pinatissecta ou bipinatissecta, com margem inteira, ou pinatipartida com margem sinuada.

20. Folhas apicais com lâmina inteira e basais com lâmina pinatissecta e com margem inteira..... 8.21. S. paucijugus

20'. Todas as folhas com lâmina pinatissecta ou bipinatissecta e com margem inteira ou pinatipartida e com margem sinuada.

21. Caule glabro; folhas com lâmina pinatissecta ou bipinatissecta e com margem inteira.

22. Folhas com lâmina bipinatissecta. 8.22. S. paulensis

22'. Folhas com lâmina pinatissecta.

23. Capítulos discoides; brácteas involucrais 8 8.16. S. leptoschizus

23'. Capítulos radiados; brácteas involucrais 10-20.

24. Segmentos da lâmina 1,5-7 mm larg.; brácteas involucrais 16-20; flores do raio 8; flores do disco 35 8.4. S. brasiliensis

24'. Segmentos da lâmina 0,5-1 mm larg.; brácteas involucrais 10-12; flores do raio 4-6; flores do disco 12 8.17. S. linearilobus

21'. Caule laxamente tomentoso; folhas com lâmina pinatipartida e com margem sinuada. 8.24. S. pseudostigophlebius

8.1 Senecio adamantinus Bong., Bull. Sci. Acad. Imp. Sci. Saint-Pétersbourg 5: 97. 1838.

Fig. $2 \mathrm{~h}$

Ervas eretas, perenes, $0,5-1 \mathrm{~m}$ alt. Caule multisulcado, fistuloso, densamente folhoso na porção basal, laxamente folhoso na porção apical, glabro a tomentoso, indumento persistente. Folhas basais com lâmina $6-17 \times(0,2-) 0,4-4,5 \mathrm{~cm}$, inteira, obovada a oblanceolada, ápice agudo a obtuso, base atenuada, margem inteira, lobada ou denteada, esparsamente lanuginosa na face adaxial, densamente albo-tomentosa na face abaxial, peninérvea, sésseis. Folhas apicais com lâmina (1-)3-9 × $(0,1-) 0,2-1,7 \mathrm{~cm}$, inteira, lanceolada a oblongo-obovada, ápice agudo a obtuso, base atenuada, margem inteira, lobada ou denteada, esparsamente lanuginosa na face adaxial, densamente albo-tomentosa na face abaxial, peninérvea, sésseis. Capitulescência corimbiforme, congesta. Capítulos heterógamos, radiados; pedúnculos 3-13 $\mathrm{mm}$ compr., lanuginosos; bractéolas lanceoladas, 3-4 mm compr., glabras. Invólucro 5-6 × 5 mm, caliculado; brácteas do calículo 4, ca. $2,5 \mathrm{~mm}$ compr., lanceoladas; brácteas involucrais 7-8, oblongas, ápice agudo, piloso, margem escariosa, dorso glabro; eixo da inflorescência plano, alveolado. Flores do raio 2-3, corola amarela, tubo $2-3 \mathrm{~mm}$ compr., limbo 4-4,5 × 1,5 mm, 4-nervada, ápice 2-3-dentado, estilete 4-4,5 mm compr., ramos do estilete ca. 1,5 $\mathrm{mm}$ compr. Flores do disco 6-9, corola ca. $6 \mathrm{~mm}$ compr., 5-lobulada, lóbulos ca. 1,5 mm compr., anteras ca. 2,5 mm compr., exsertas, apêndice do conectivo ca. $0,5 \mathrm{~mm}$ compr., oblongo-deltóide, base obtusa; estilete ca. $5 \mathrm{~mm}$ compr., ramos do estilete ca. $2 \mathrm{~mm}$ compr. Cipselas ca. 1,5 mm compr., cilíndricas a obcônicas, 8-costeladas, glabras; pápus 4-5 mm compr., persistente.

Material selecionado: Diamantina, $18^{\circ} 15^{\prime} 01^{\prime \prime} \mathrm{S}$, 4339'08'W, 13.II.2001, J.R. Stehmann et al. 2715 (BHCB). Lima Duarte, $21^{\circ} 41^{\prime} 03^{\prime \prime} \mathrm{S}, 43^{\circ} 53^{\prime} 01^{\prime \prime} \mathrm{W}$, 5.II.2004, R.C. Forzza 2660 (BHCB, RB). Ouro Preto, $1.807 \mathrm{~m}, 20^{\circ} 13^{\prime} 7,7^{\prime \prime} \mathrm{S}, 43^{\circ} 34^{\prime} 52,2^{\prime \prime} \mathrm{W}, 12$.VII.2007, A.M. Teles et al. 486 (BHCB).

Espécie muito comum nos estados da região Sudeste do Brasil, ocorrendo desde Minas Gerais até Santa Catarina, tendo provavelmente o norte de Santa Catarina como o limite austral de distribuição (Cabrera \& Klein 1975). Ocorre em campos limpos brejosos, campos rupestres, campos arenosos úmidos e campos de altitude, em altitudes que variam de 700 a 2.000 m.s.m. Fértil de setembro a fevereiro.

Senecio adamantinus pertence à seção Adamantina (Cabrera 1957) e tem como espécie morfologicamente mais próxima $S$. colpodes, porém diferencia-se desta pelo número de brácteas involucrais que são 7-8 (versus 10-12) e pelo número de flores do raio que são de $2-3$ (versus 7-8). Difere ainda de S. pseudostigophlebius pela margem foliar inteira, lobada ou denteada (versus pinatiloba ou pinatipartida) e pelo número de flores do raio 2-3 (versus 6-10). Baker (1884) e Cabrera (1957) reconheceram duas variedades para essa espécie, a variedade típica e $S$. adamantinus var. integrifolius Baker, que diferencia-se da variedade típica por possuir folhas inteiras ou escassamente denteadas, especialmente as basais (Cabrera 1957). 
8.2 Senecio albus J.N. Nakaj. \& A. Teles, Kew Bull. 64: 161-165. 2009.

Fig. 2i-k

Ervas perenes, ca. 1,5 m alt. Raízes fibrosas. Caule simples, estriado, meduloso, densamente folhoso na porção basal, laxamente folhoso na porção apical, densamente albo-tomentosoaracnoideo. Folhas gradativamente menores apicalmente, lâmina 3,5-10,8 × 1,2-3,4 cm, inteira, elíptico-lanceolada a lanceolada, ápice obtuso, base auriculada, margem esparsamente crenado-denteada, dentes obtusos, nervuras secundárias reticuladas na face abaxial, densamente albo-tomentosa em ambas as faces, peninérvea, sésseis, semi-amplexicaules. Capitulescência terminal, paniculiforme, eixos corimbiformes, denso albo-tomentosos. Capítulos homógamos, discoides; pedúnculos 1-4 mm compr., albotomentosos; bractéolas 3-4 mm compr., lanceoladas a linear-lanceoladas, densamente albo-tomentosas. Invólucro 5-7 × 3-4 mm, caliculado; brácteas do calículo 4, 3-3,5 mm compr., lanceoladas; brácteas involucrais 7-8, lanceoladas, ápice agudo, penicelado, margem escariosa, dorso glandulosopontuado e glabrescente; eixo da inflorescência plano, piloso. Flores 9-14, corola 6-6,5 mm compr., 5-lobulada, lóbulos ca. 1,5 mm compr., anteras 1,5-1,7 mm compr., exsertas, apêndice do conectivo $0,3-0,5 \mathrm{~mm}$ compr., oblongo, base obtusa; estilete $6-6,5 \mathrm{~mm}$ compr., ramos do estilete ca. $2 \mathrm{~mm}$ compr. Cipselas 1,5-2 mm compr., cilíndricas, 10-costeladas, glabras, setoso; pápus 5-5,5 mm compr., caduco.

Material examinado: Delfinópolis, 2020'33"S, $46^{\circ} 46^{\prime} 02^{\prime \prime}$, alt. 996 m, 6.XII.2002, J.N. Nakajima et al. 3385 (HUFU, S). São Roque de Minas, 28.VI.1994, R. Romero \& J.N. Nakajima 1069 (HUFU, holótipo; S, isótipo).

Ocorrência conhecida até o momento apenas para Minas Gerais, onde é encontrada no Parque Nacional da Serra da Canastra, município de São Roque de Minas, e em Delfinópolis, em campo úmido após queimada. Fértil em junho e dezembro.

Senecio albus pertence à seção Adamantina Cabrera e tem como espécie morfologicamente afim $S$. gertii, diferindo desta pelo menor número de brácteas involucrais e pelo indumento que as revestem (7-8, glanduloso-pontuadas e glabrescentes versus 12-13, densamente albotomentosas). Além disso, S. albus possui 9-14 flores, enquanto que $S$. gertii possui 35. Senecio albus, juntamente com $S$. gertii, são as únicas espécies dessa seção que possuem capítulos discoides; as demais espécies da seção possuem capítulos radiados. Senecio dumetorum pode ser confundida com $S$. albus, pelo aspecto vegetativo, porém difere pelos capítulos radiados.

8.3 Senecio altimontanus A. Teles \& L.D. Meireles, Brittonia 62(2): 178-182. 2010

Fig. 21-o

Ervas a subarbustos perenes, $38-55 \mathrm{~cm}$ alt. Caule avermelhado, normalmente simples a raramente ramificado, cicatricoso, meduloso, densamente folhoso na porção apical, esparsamente folhoso a áfilo na porção basal, glabro. Folhas com lâmina 1,7-4 ×0,3-0,8 cm, inteira, oblanceolada, ápice agudo, base atenuada, não auriculada, margem serreada na metade distal, revoluta, esparsamente vilosa na face adaxial, glabra na face abaxial, uninérvea, sésseis. Capítulos solitários ou 3-5, agrupados em capitulescência corimbiforme. Capítulos heterógamos, radiados; pedúnculos 10-25 mm compr., tomentosos; bractéolas lanceoladas, $0,5-1,5 \mathrm{~mm}$ compr., glabras. Invólucro 10-11 × 12-15 mm, caliculado; brácteas do calículo 7 , linear-lanceoladas, $8-9 \mathrm{~mm}$ compr.; brácteas involucrais 10, lanceoladas, ápice agudo, penicelado, margem escariosa, glabras, dorso 3-nervado; eixo da inflorescência convexo, alveolado. Flores do raio 12-14, corola amarela, tubo $4 \mathrm{~mm}$ compr., limbo ca. $14 \times 4 \mathrm{~mm}$, 4-nervada, ápice 3-dentado, estilete ca. $7 \mathrm{~mm}$ compr., ramos do estilete ca. $2 \mathrm{~mm}$ compr. Flores do disco 50, corola 6-7 mm compr, 5-lobulada, lóbulos ca. 1,5 $\mathrm{mm}$ compr., anteras $2-2,5 \mathrm{~mm}$ compr., exsertas, apêndice do conectivo $0,5-1 \mathrm{~mm}$ compr., oblongo, base obtusa; estilete ca. $7 \mathrm{~mm}$ compr., ramos do estilete ca. $2 \mathrm{~mm}$ compr. Cipselas cilíndricas, 3-3,5 $\mathrm{mm}$ compr., 10-costeladas, glabras; pápus $5-6 \mathrm{~mm}$ compr., persistente.

Material selecionado: Passa Quatro, 2.664-2.792 m, $22^{\circ} 25^{\prime} 33,7^{\prime \prime} \mathrm{S}, 44^{\circ} 50^{\prime} 31,8^{\prime} \mathrm{W}, 7 . \mathrm{VI} .2006$, L.D. Meireles et al. 2396 (UEC, holótipo; BHCB, RB, S, isótipos). $523 \mathrm{~m}, 22^{\circ} 54^{\prime} 40,9^{\prime \prime} \mathrm{S}, 44^{\circ} 50^{\prime} 6,8^{\prime \prime} \mathrm{W}, 31$.VIII.2007, L.D. Meireles et al. 3300 (BHCB, UEC). 2.498-2.612 m, $22^{\circ} 25^{\prime} 16,3$ ”'S, 4450'52,2”'W, 15.V.2005, L.D. Meireles et al. 1657 (BHCB, UEC).

Ocorre em Minas Gerais e São Paulo, em campos de altitude acima de 2.500 m.s.m. Fértil de fevereiro a julho.

Senecio altimontanus pertence à seção Corymbocephalus Cabrera subseção Simplices. Dentre as espécies encontradas em Minas Gerais, S. altimontanus assemelha-se mais a $S$. apensis Cabrera, espécie encontrada no Paraguai e no Brasil (Mato Grosso e Mato Grosso do Sul). No 
entanto, difere desta em vários aspectos, tais como forma da lâmina foliar oblanceolada e serreada na metade superior da lâmina (versus lanceolada e uniformemente serreada na margem), tamanho das folhas $1,7-4 \times 0,3-0,8 \mathrm{~cm}$ (versus $6-12 \times 1-3$ $\mathrm{cm}$ ), número de brácteas involucrais 10 (versus 20) e no indumento das cipselas (glabra versus papilosa-seríceas).

8.4 Senecio brasiliensis (Spreng.) Less., Linnaea 6: 249.1831.

Ervas a arbustos eretos, perenes, até $2 \mathrm{~m}$ alt. Caule multisulcado, fistuloso, densamente folhoso por toda a extensão, glabro. Folhas com lâmina $4-18 \times 0,2-8 \mathrm{~cm}$, pinatissecta, segmentos 2-7-jugos, 15-60 × 1,5-7 mm, lineares a linear-lanceolados, ápice agudo, base atenuada, não amplexicaule, margem inteira, glabros na face adaxial, albo-tomentosos na face abaxial, peninérveos, sésseis. Capitulescência paniculadocorimbiforme, laxa. Capítulos heterógamos, radiados, pedunculados; pedúnculos $0,7-4 \mathrm{~cm}$ compr., glabros; bractéolas 2-3 mm compr., lanceoladas, glabras. Invólucro 10-11 × 5-6 mm, caliculado; brácteas do calículo 7, lanceoladas, 2-3 mm compr.; brácteas involucrais 16-20, oblongas, ápice agudo a obtuso, glabro, margem escariosa, dorso glabro; eixo da inflorescência plano, fimbriado. Flores do raio 8 , corola amarela, tubo ca. $6 \mathrm{~mm}$ compr., limbo ca. $7 \times 3 \mathrm{~mm}$, 4-nervada, ápice 3-dentado, estilete $7-8 \mathrm{~mm}$ compr., ramos do estilete ca. 2,5 mm compr. Flores do disco 35, corola 8,5-9 mm compr, 5-lobulada, lóbulos ca. 1 $\mathrm{mm}$ compr., anteras ca. 2,5 mm compr., exsertas, apêndice do conectivo ca. 0,5 mm compr., oblongodeltóide, base obtusa; estilete 9-9,5 mm compr., ramos do estilete ca. $2 \mathrm{~mm}$ compr. Cipselas 2,5-3 mm compr., cilíndricas, 8-costeladas, glabras; pápus 5,5-8 mm compr., caduco.

Material selecionado: Camanducaia, 22 41 '31'S, 4557'36"W, 22.VI.2000, L.H.Y. Kamino et al. 78(BHCB, UEC). Passa Quatro, 1.575-2.024 m.s.m, 22²6'58,4”S, 4453'49,6”W, 9.VIII.2005, L.D. Meireles \& J.A. Nunes 1907 (BHCB, UEC). Santa Bárbara, 1.637 m, 2003'24”S, 4341'28,6”W, 20.X.2007, F.F. Carmo 1222 (BHCB).

Ocorre em todos os estados das Regiões Sul e Sudeste e em Goiás. Em Minas Gerais, ocorre em campos de altitude, margens de estradas, brejos, margens de córregos, campos rupestres e em florestas submontanas e montanas. Fértil de junho a março.

Senecio brasiliensis faz parte do grupo de espécies de Senecio com lâmina foliar pinatissecta
(Senecio sect. Corymbocephalus subsect. Brasilienses) (Cabrera 1957). Tem como espécie morfologicamente afim S. linearilobus Bong., porém, difere desta por possuir os segmentos da lâmina foliar mais largos (1,5-7 mm larg. versus $0,5-1 \mathrm{~mm}$ larg.), pelo maior número de brácteas involucrais (16-20 versus 10-12), pelo maior número de flores do raio (8 versus 4-6) e do disco (35 versus 12). Baker (1884), Cabrera (1957) e Matzenbacher (1998) reconheceream duas variedades para a espécie, a variedade típica e S. brasiliensis var. tripartitus (DC.) Baker. A segunda diferencia-se basicamente da primeira pelos segmentos serrados, mais largos (até $8 \mathrm{~mm}$ compr.) e em menor número (Cabrera 1957).

Iconografias em Cabrera (1974: 446, fig. 263), Cabrera \& Klein (1975: 180, est. 51) e Moraes \& Monteiro (2006: 45, fig. 11).

Nomes vernaculares: cravo-do-campo, ervalanceta, flor-das-almas, maria-mole, senecio e tasneirinha.

8.5 Senecio caparaoensis Cabrera, Arch. Jard. Bot. Rio de Janeiro 15: 223. 1957.

Ervas eretas, perenes, até $1 \mathrm{~m}$ alt. Caule multisulcado, fistuloso, densamente folhoso por toda a extensão, gríseo-lanoso, indumento persistente. Folhas com lâmina $5-20 \times 1,5-5 \mathrm{~cm}$, inteira, oblanceolada, ápice agudo, acuminado a obtuso, base atenuada, semi-amplexicaule, curtamente auriculado-decorrente, margem serreada ou denteada, dentes mucronulados, lanuginosa na face adaxial, densamente tomentosa na face abaxial, peninérvea, sésseis. Capitulescência corimbiforme, congesta. Capítulos heterógamos, radiados; pedúnculos 1,5-2 cm compr., tomentosos; bractéolas lanceoladas. Invólucro ca. $10 \times 10-12$ $\mathrm{mm}$, caliculado; brácteas do calículo lineares, lanuginosas; brácteas involucrais 13, lanceoladas, ápice agudo, piloso, margem escariosa, dorso lanuginoso; eixo da inflorescência plano, glabro. Flores do raio 10-15, corola amarela, tubo ca. $2,5 \mathrm{~mm}$ compr., limbo ca. $14 \times 3 \mathrm{~mm}$. Flores do disco 45-50, corola ca. $8 \mathrm{~mm}$ compr., 5-lobulada. Cipselas cilíndricas, glabras; pápus alvacento.

Material examinado: Alto Caparaó, 24.IX.1941, A.C. Brade 17008 (RB, isótipo). 9.III.2010, G. Heringer et al. 406 (BHCB). 11.IV.2010, G.O. Romão 2725 (RB).

Ocorre em Minas Gerais e Santa Catarina. Em Minas Gerais é rara e restrita à Serra do Caparaó, em campo de altitude. Fértil em setembro.

Senecio caparaoensis pertence à seção Adamantina Cabrera (Cabrera 1957) e tem como 
espécie morfologicamente afim S. colpodes, porém difere pelo caule folhoso em toda a extensão, lâmina foliar com margem serreada a denteada e capítulos com 10-15 flores do raio. Já S. colpodes possui o caule densamente folhoso na porção basal e esparsamente folhoso (a quase áfilo) na porção apical, lâmina foliar com margem crenado-lobada e capítulos com 7-8 flores do raio.

Iconografias em Cabrera (1957: 290, fig. 21) e Cabrera \& Klein (1975: 216, est. 62).

8.6 Senecio claussenii Decne., Rev. Hortic., 4: 181. 1855.

Fig. $2 p$

Ervas eretas, perenes, até $2 \mathrm{~m}$ alt. Caule multisulcado, fistuloso, esparsamente folhoso por toda a extensão, albo-tomentoso, indumento caduco. Folhas com lâmina $2-12 \times 0,8-5 \mathrm{~cm}$, inteira, ovada, ápice agudo, base obtusa, margem crenado-denteada, densamente albo-tomentosa em ambas as faces, peninérvea; pecíolos 0,6$4 \mathrm{~cm}$ compr., cilíndricos, albo-tomentosos, auriculados na base, aurículas 3-8 × 4-15 mm, reniformes, albo-tomentosas. Capitulescência paniculado-corimbiforme, congesta. Capítulos heterógamos, radiados; pedúnculos $0,6-1,8 \mathrm{~cm}$ compr., glabrescentes; bractéolas 2-4 mm compr., lanceoladas, glabrescentes. Invólucro 7-8 × 7-12 $\mathrm{mm}$, caliculado; brácteas do calículo 8 , lanceoladas, 2-4 mm compr.; brácteas involucrais 13 , oblongolanceoladas, ápice agudo, piloso, margem escariosa, dorso glabro; eixo da inflorescência plano, alveolado. Flores do raio 8 , corola amarela, tubo ca. $5 \mathrm{~mm}$ compr., limbo ca. $14 \times 4 \mathrm{~mm}$, 4-nervada, ápice 2-dentado, estilete ca. $6,5 \mathrm{~mm}$ compr., ramos do estilete ca. $2 \mathrm{~mm}$ compr. Flores do disco 70, corola 6,5-7 mm compr., 5-lobulada, lóbulos ca. 2 $\mathrm{mm}$ compr., anteras ca. $2 \mathrm{~mm}$ compr., exsertas, base sagitada, apêndice do conectivo ca. $0,5 \mathrm{~mm}$ compr., oblongo-deltoide; estilete ca. 9,5 mm compr., ramos do estilete ca. 1,5 mm, compr. Cipselas ca. 2,5 mm compr., cilíndricas, 8-costeladas, seríceopubescentes; pápus 5-7 mm compr., caduco.

Material selecionado: Catas Altas, $1.800 \mathrm{~m}, 11 . \mathrm{VI} .1998$, M.F. Vasconcelos (BHCB 42695). 25.V.2001, R.C. Mota 318 (BHCB).

Endêmica de Minas Gerais, ocorrendo em campos rupestres e campos de altitude, entre 1.300 a 1.950 m.s.m. Fértil de janeiro a agosto.

Senecio claussenii pertence à seção Paranaia Cabrera (Cabrera 1957) e por possuir indumento albo-tomentoso lembra o grupo de espécies de Senecio com esse tipo de indumento, que inclui $S$. albus, S. dumetorum, S. gertii, $S$. hatschbachii, S. hemmendorffii, S. macrotis e $S$. pseudostigophlebius. Difere de S. albus, $S$. gertii, $S$. hatschbachii e $S$. macrotis por possuir capítulos radiados; de $S$. dumetorum e de $S$. pseudostigophlebius pelas folhas distintamente pecioladas; e de S. hemmendorffii principalmente por possuir folhas com lâmina ovada, crenadodenteada e albo-tomentosa em ambas as faces (versus folhas com lâmina elíptica ou obovadoelíptica, lirado-pinatissecta e albo-tomentosa somente na face abaxial).

8.7 Senecio colpodes Bong., Bull. Sci. Acad. Imp. Sci. Saint-Pétersbourg 5: 98. 1838 Fig. 2q

Ervas a arbustos eretos, perenes, 0,5-1 m alt. Caule multisulcado, fistuloso, densamente folhoso na porção basal, laxamente folhoso na porção apical, hirsuto-glanduloso. Folhas com lâmina 1,5-12 × 0,3-4 cm, inteira, oblongoespatulada, ápice obtuso, base atenuada, margem crenado-lobada, 1-nervura por lobo, nervuras conspícuas na face abaxial, hirsuto-glandulosa na face adaxial, densamente albo-tomentosa na face abaxial, peninérvea, sésseis. Capitulescência paniculado-corimbiforme, congestas. Capítulos heterógamos, radiados; pedúnculos 3-27 mm compr., hirsuto-glandulosos; bractéolas 4-10 mm compr., lanceoladas, hirsuto-glandulosas. Invólucro 6-9 × 4-6 mm, caliculado; brácteas do calículo 6, lanceoladas, ca. $4 \mathrm{~mm}$ compr.; brácteas involucrais 10-12, lanceoladas, ápice agudo, piloso, margem escariosa, dorso glabro; eixo da inflorescência plano, alveolado. Flores do raio $7-8$, corola amarela, tubo ca. 2,5 mm compr., limbo ca. $8 \times$ 2,5 mm, 4-nervada, ápice 3-dentado; estilete ca. 6,5-7 mm compr., ramos do estilete ca. $1,5 \mathrm{~mm}$ compr. Flores do disco 18-20, corola ca. $7 \mathrm{~mm}$ compr., 5-lobulada, lóbulos ca. 1,5 mm compr., anteras ca. $2 \mathrm{~mm}$ compr., base obtusa, apêndice do conectivo ca. 0,5 mm compr., oblongo; estilete ca. 7 $\mathrm{mm}$ compr. Cipselas ca. $2 \mathrm{~mm}$ compr., cilíndricas, 8-10-costeladas, glabras; pápus 5-6 mm compr., persistente.

Material selecionado: Rio Preto, 1.600 m, 21.I.2006, F.S. Souza et al. 132 (CESJ). Santana do Riacho, 19 13'13'S, 4329'57'W, 5.VII.2001, V.C. Souza et al. 25129 (ESA). Santo Antônio do Itambé, 5.X.2006, A.M. Teles 258 (BHCB).

Endêmica de Minas Gerais, ocorre em campos rupestres e campos de altitude. Fértil de maio a dezembro.

Senecio colpodes pertence à seção Adamantina Cabrera (Cabrera 1957) e pode ser 
confudida com algumas formas de $S$. adamantinus com lâminas foliares lobadas, contudo, difere desta pelo maior número de brácteas involucrais (10-15 versus 7-8) e de flores do raio (7-8 versus 2-3). Pode ser confundia com $S$. caparaoensis, porém difere pelas folhas que são congestas na porção basal e laxas na porção apical e pelo menor número de flores do raio (7-8), enquanto que em $S$. caparaoensis as folhas estão dispostas uniformemente ao longo de todo o caule e as flores do raio são em número de 10-15.

8.8 Senecio dumetorum Gardner, London J. Bot. 7: 422.1848.

Ervas eretas, perenes, 1-4 $\mathrm{m}$ alt. Caule multisulcado, fistuloso, densamente folhoso na porção basal, laxamente folhoso na porção apical, densamente albo-lanoso. Folhas basais com lâmina 8-17 × 2,5-7 cm, inteira, oblanceolada, ápice obtuso, base decorrente, margem irregularmente serreada, dentes obtusos, densamente albolanosa em ambas as faces, peninérvea, sésseis. Folhas apicais gradativamente menores, lâmina lanceolada, ápice agudo, base decorrente, margem irregularmente serreada, dentes obtusos, densamente albo-tomentosa em ambas as faces, sésseis. Capitulescência corimbiforme, congesta. Capítulos heterógamos, radiados; pedúnculos 8-28 mm compr., glabros a tomentosos; bractéolas 2-4 mm compr., lanceoladas, glabras a tomentosas. Invólucro 6-7 × 7-10 mm, caliculado; brácteas do calículo 4, 2-4 mm compr., lanceoladas; brácteas involucrais 12-15, lanceoladas, ápice agudo, glabro, margem escariosa, dorso glabro; eixo da inflorescência plano, alveolado. Flores do raio 6-8, corola amarela, tubo ca. $4 \mathrm{~mm}$ compr., limbo ca. $7 \times 3 \mathrm{~mm}, 4$-nervada, ápice 3-dentado; estilete ca. $5 \mathrm{~mm}$ compr., ramos do estilete ca. 1 $\mathrm{mm}$ compr. Flores do disco 40, corola ca. $7 \mathrm{~mm}$ compr., 5-lobulada, lóbulos ca. $1 \mathrm{~mm}$ compr., anteras ca. 2,5 mm compr., base obtusa, apêndice do conectivo ca. 0,5 mm compr., oblongo; estilete ca. $7 \mathrm{~mm}$ compr. Cipselas ca. $3 \mathrm{~mm}$ compr., cilíndricas, 10-costeladas, papilosas; pápus 5-7 mm compr., caduco.

Material selecionado: Buenópolis, 19.VIII.2002, G. Hatschbach et al. 73592 (MBM). Itacambira, 29.XI.1984, M.L. Kawazaki et al. CFCR 6598 (SPF). Joaquim Felício, $1.228 \mathrm{~m}, 1^{\circ} 42^{\prime} 8,4^{\prime \prime S}, 4^{\circ} 17^{\prime} 50^{\prime} \mathrm{W}$, 15.XI.2007, A.M. Teles \& P.L. Viana 496 (BHCB).

Endêmica de Minas Gerais, ocorre em campos rupestres, entre 1.000 e 1.200 m.s.m. Fértil de julho a novembro.
Senecio dumetorum pertence à seção Adamantina e caracteriza-se pelo indumento densamente albo-tomentoso que reveste toda a planta, pelas folhas sésseis com a base decorrente e pelos capítulos radiados. Assemelha-se à $S$. albus e a $S$. gertii, porém difere de ambas pelos capítulos radiados.

8.9 Senecio emiliopsis C. Jeffrey, Kew Bull. 47: 95. 1992.

Ervas eretas, perenes, ca. 1,5 m alt. Caule multisulcado, meduloso, densamente folhoso na porção basal, laxamente folhoso na porção apical, pubescente. Folhas basais com lâmina 6-9 $\times$ 1-2 cm, inteira, oblanceolada, ápice agudo, base atenuada, margem serreada, ciliada, dentes agudos, glabra na face adaxial, tomentosa na face abaxial, peninérvea, sésseis. Folhas apicais com lâmina 1,5$4 \times 0,1-0,5 \mathrm{~cm}$, inteira, lanceolada, ápice agudo, base atenuada, margem serreada, dentes agudos, glabra na face adaxial, tomentosa na face abaxial, peninérvea, sésseis. Capitulescência corimbiforme, laxa. Capítulos homógamos, discoides; pedúnculos 7-15 mm compr., pubescentes; bractéolas 3-10 mm compr., lanceoladas, pubescentes. Invólucro 7-10 $\times 10-15 \mathrm{~mm}$, caliculado; brácteas do calículo 15 , 3-4 mm compr., lanceoladas; brácteas involucrais 20, oblongas, ápice agudo, piloso, margem escariosa, dorso glabro; eixo da inflorescência plano, alveolado. Flores 70, corola $5-5,5 \mathrm{~mm}$ compr., 5-lobulada, lóbulos ca. $1 \mathrm{~mm}$ compr., anteras ca. $2 \mathrm{~mm}$ compr., base obtusa, apêndice do conectivo 0,5-0,7 mm compr., oblongo; estilete 5,5-6 mm compr., ramos do estilete 1-1,5 mm compr. Cipselas 1-1,5 mm compr., cilíndricas, 10-costeladas, glabras; pápus 5-6 mm compr., persistente.

Material examinado: São Roque de Minas, 18.III.1995, J.N. Nakajima et al. 825 (HUFU, UEC).

Endêmica de Minas Gerais, ocorre em campos rupestres. Fértil em março.

Senecio emiliopsis pertence à seção Corymbocephalus Cabrera subseção Simplices (Cabrera 1957), e é semelhante a S. pohlii, diferindo pelo indumento das folhas (Baker 1884). Senecio emiliopsis foi originalmente descrita por Baker (1884) sob o epíteto específico de " $S$. emilioides". No entanto, esse epíteto já havia sido anteriormente ocupado por uma espécie da África [S. emilioides Sch.Bip., atualmente Emilia emilioides (Sch.Bip.) C.Jeffrey], o que levou Jeffrey (1992) a propor um nome novo para a espécie, S. emiliopsis. 
8.10 Senecio erisithalifolius Sch. Bip. ex Baker, Fl. bras. 6(3): 321. 1884.

Ervas robustas, eretas, perenes, 1-3 $\mathrm{m}$ alt. Caule multisulcado, fistuloso, densamente folhoso na porção basal, laxamente folhoso na porção apical, glabro. Folhas basais com lâmina 13-40 $\times 5-25 \mathrm{~cm}$, pinatissecta, segmentos 6-11-jugos, $2-11,5 \times 0,3-3 \mathrm{~cm}$, lanceolados, ápice agudo, margem inteira a denteada, glabros na face adaxial, hirsutos na face abaxial, peninérvea; pecíolos 5,5-8,5 cm compr., cilíndricos, invaginantes na base, auriculas ausentes, glabros. Folhas da porção média com lâmina $22-40 \times 3-5,5 \mathrm{~cm}$, inteira, lanceolada, ápice agudo, base truncada, margem denteada a irregularmente fendida, glabra na face adaxial, hirsuta na face abaxial, peninérvea, sésseis. Folhas apicais com lâmina 3-12 × 1-5 mm, inteira, linear a lanceolada, ápice agudo, base atenuada, margem inteira, glabra na face adaxial, hirsuta na face abaxial, peninérvea, sésseis. Capitulescência panículado-corimbiforme, laxa. Capítulos heterógamos, radiados; pedúnculos 4-65 mm compr., hirsuto-glandulosos; bractéolas 4-12 mm compr., lanceoladas, hirsuto-glandulosas. Invólucro 10-13 × 11-15 mm, caliculado; brácteas do calículo 7 , ca. $5 \mathrm{~mm}$ compr., lanceoladas; brácteas involucrais 24 , lanceoladas, ápice agudo, piloso, margem escariosa, dorso hirsuto; eixo da inflorescência plano, alveolado. Flores do raio 10-13, corola lilás, tubo 5-6 mm compr., limbo ca. $17 \times 3 \mathrm{~mm}$, 4-nervada, ápice 3-dentado; estilete ca. $6,5 \mathrm{~mm}$ compr., ramos do estilete ca. $1,5 \mathrm{~mm}$ compr. Cipselas cilíndricas, ca. $2 \mathrm{~mm}$ compr., glabras; pápus 5-6 $\mathrm{mm}$ compr., persistente. Flores do disco 55-60, corola 8-9 mm compr., 5-lobulada, lóbulos ca. $1 \mathrm{~mm}$ compr., anteras ca. $2 \mathrm{~mm}$ compr., base obtusa, apêndice do conectivo ca. $0,5 \mathrm{~mm}$ compr., oblongo; estilete ca. $8 \mathrm{~mm}$ compr., ramos do estilete 1-1,5 mm compr. Cipselas ca. $2 \mathrm{~mm}$ compr., cilíndricas, 8-10-costeladas, glabras; pápus 5-7 mm compr., persistente.

Material examinado: Camanducaia, 27.IV.2001, W. Marcondes-Ferreira 1727 (ESA, UEC). Carandaí, $20^{\circ} 52^{\prime} 40,5^{\prime}$ 'S, 4349'01,4”'W, 8.XI.2006, N.F. Mota \& D.

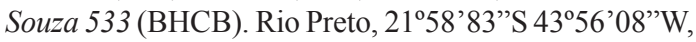
23.II.2004, F.R.G. Salimena et al. 1210 (CESJ).

Ocorre em Minas Gerais e São Paulo (Hind 1993). Em Minas Gerais, ocorre em áreas pantanosas como brejos e campos de várzea. Fértil de novembro a abril.

Senecio erisithalifolius pertence à seção Hualtata Cabrera (Cabrera 1957) e tem como espécie morfologicamente afim S. icoglossus; difere desta por possuir folhas basais com lâmina pinatissecta, enquanto que $S$. icoglossus possui todas as folhas com lâmina inteira ou quando muito dentado-crenada. Essas duas espécies são as únicas em Minas Gerais com flores do raio lilases. Além disso, se caracterizam por serem paludícolas, como as demais espécies da seção.

Iconografia em Cabrera (1957: 234, lam. III).

8.11 Senecio gertii Zardini, Bol. Mus. Bot. Munic. 37: 1. 1979.

Ervas a arbustos eretos, perenes, 1-4 m alt. Caule multisulcado, meduloso, densamente folhoso na porção basal, laxamente folhoso na porção apical, densamente lanuginoso. Folhas basais com lâmina $7-24 \times 1,5-12 \mathrm{~cm}$, inteira, ovada a obovada, ápice agudo, base atenuada, auriculada, aurículas 0,5-2 × $1-2 \mathrm{~cm}$, reniformes, densamente lanuginosa em ambas as faces, margem irregularmente crenado-denteada, dentes obtusos, nervuras imersas na face adaxial, conspícuas na face abaxial, densamente lanuginosa em ambas as faces, peninérvea, sésseis. Folhas apicais com lâmina 2-5 $\times 0,2-2,5 \mathrm{~cm}$, inteira, oblonga a lanceolada, ápice agudo, base truncada, auriculada, margem inteira a denteada, densamente lanuginosa em ambas as faces, peninérvea, sésseis. Capitulescência paniculado-corimbiforme, congesta. Capítulos homógamos, discoides; pedúnculos 3-10 mm compr., densamente lanuginosos; bractéolas 4-5 $\mathrm{mm}$ compr., lanceoladas, densamente lagunigosas. Invólucro 8-10 × 7-9 mm, calículado; brácteas do calículo 6 , 3-4 mm compr., lanceoladas; brácteas involucrais 13, oblongas, ápice agudo, piloso, margem escariosa, dorso densamente lanuginoso; eixo da inflorescência plano, alveolado. Flores 35, corola 6-7 mm compr., 5-lobulada, lóbulos 2-3 mm compr., anteras ca. $2,5 \mathrm{~mm}$ compr., base sagitada, apêndice do conectivo ca. $0,5 \mathrm{~mm}$ compr., oblongo; estilete ca. $9 \mathrm{~mm}$ compr., ramos do estilete ca. $2 \mathrm{~mm}$ compr. Cipselas 2,5-3,5 mm compr., cilíndricas, 5-costeladas, papilosas nas costelas; pápus 6-7 mm compr., caduco.

Material selecionado: Grão Mogol, 22.VII.1978, G. Hatschbach 41467 (MBM, holótipo). 16 33'-16²3's, 42 ${ }^{\circ} 54^{\prime}-32^{\circ} 55^{\prime} \mathrm{W}$, 6.IX.1990, J.R. Pirani et al. CFCR 13438 (SPF, UEC). 975 m, 16 $33^{\circ} 4,8^{\prime}$ 'S, 4253'55,5”'W, 18.XI.2007, A.M. Teles \& P.L. Viana 518 (BHCB).

Endêmica de Grão Mogol, em Minas Gerais, ocorre em áreas arenosas dos campos rupestres, entre 970 a 1.200 m.s.m. Fértil de julho a novembro.

Senecio gertii pertence à seção Adamantina e juntamente com Senecio albus são as únicas 
espécies da seção com capítulos discoides. Diferencia-se de $S$. albus pelas folhas com lâmina serreada e base auriculada e de Senecio dumetorum, espécie morfologicamente afim, pelos capítulos discoides e brácteas involucrais lanuginosas (versus capítulos radiados e brácteas involucrais glabras de S. dumetorum Gardner) (Zardini 1979).

Iconografias em Zardini (1979: 3, lam. 1; p. 4, lam. 2; p. 5, lam. 3).

8.12 Senecio grandis Gardner, London, J. Bot. 7: 422. 1848 .

Fig. 2r

Ervas eretas, robustas, perenes, 1,5-4 m alt. Caule multisulcado, fistuloso, laxamente folhoso por toda a extensão, esparsamente aracnóideo-lanuginoso Folhas com lâmina 30-60 $\times 15-25 \mathrm{~cm}$, inteira, ovado-oblonga, ápice agudo, base arredondada, margem inteira a denteada, dentes agudos, glabrescente na face adaxial, densamente albo-tomentosa a purpúreo-tomentosa na face abaxial, peninérvea; pecíolos $10-17 \mathrm{~cm}$ compr., canaliculados a estreitamente alados. Capitulescência paniculiforme, congesta, até 2 m compr. Capítulos homógamos, discoides; pedúnculos 10-15 mm compr., glabrescentes; bractéolas 2-3 mm compr., lanceoladas, ciliadas. Invólucro 10-11 × 4-5 mm, caliculado; brácteas do calículo 5, 2-4 mm compr., lanceoladas; brácteas involucrais 7-8, oblongas, ápice agudo, piloso, margem escariosa, dorso glabro, 3-nervadas; eixo da inflorescência plano, alveolado. Flores 8-15, corola 8-9 mm compr., 5-lobulada, lóbulos ca. $2 \mathrm{~mm}$ compr., anteras ca. 2,5 mm compr., base obtusa, apêndice do conectivo ca. 0,5 mm compr., oblongo; estilete ca. $10 \mathrm{~mm}$ compr., ramos do estilete ca. $3 \mathrm{~mm}$ compr. Cipselas ca. $3 \mathrm{~mm}$ compr., cilíndricas, 10-costeladas, glabras; pápus ca. $7 \mathrm{~mm}$ compr., persistente.

Material examinado: Conceição, VIII.1840, Gardner 4939 (BM, lectótipo; K, isolectótipo). Itabira, 24.VIII.2006, A.M. Teles \& R.C. Mota 281 (BHCB). 3.IV.2007, A.M. Teles et al. 368 (BHCB).

Ocorre em Minas Gerais, Rio de janeiro, Espírito Santo, São Paulo e Paraná. Rara em Minas Gerais, conhecida apenas de Conceição do Mato Dentro (localidade típica) e Itabira, onde foi coletada no interior de floresta ombrófila semidecidual secundária, formando grande população com indivíduos jovens e adultos, em área úmida, próxima à córrego d'água. Fértil em abril e agosto.

Senecio grandis pertence à seção Cacaliastrum Cabrera (Cabrera 1957). Destaca- se pelo tamanho das folhas e da capitulescência, que pode chegar a $2 \mathrm{~m}$ compr., com centenas de capítulos congestos. Senecio grandis tem como espécies morfologicamente mais próximas em Minas Gerais, S. macrotis e S. hatschbachii, diferindo pelo tamanho e forma das folhas e dos pecíolos. Enquanto $S$. grandis possui folhas com lâmina ovado-oblonga, com 30-60× 15-25 cm. e pecíolos com 10-17 cm compr., S. macrotis possui folhas com lâmina lirado-pinatissectas, com 15-26 × 6-13,5 cm e pecíolos 3,5-8 cm compr. Já S. hatschbachii possui folhas com lâmina ovadoelíptica, e pecíolos com 0,8-4,3 cm compr.

8.13 Senecio hatschbachii Cabrera, Bol. Mus. Bot. Munic. 15: 1. 1974.

Fig. 2s

Ervas eretas, perenes, 1-2 $\mathrm{m}$ alt. Caule multisulcado, fistuloso, densamente folhoso na porção mediana, laxamente folhoso nas porções apical e basal, densamente albo-tomentoso. Folhas com lâmina $(3-) 4,7-12,7(-17,5) \times$ $(1,1-) 3,2-5,3(-10,9) \mathrm{cm}$, concolor, cinérea, inteira, ovado-elíptica, ápice agudo a obtuso, base atenuada, margem irregularmente denteada, dentes agudos, densamente albo-tomentosa em ambas as faces, peninérvea; pecíolos 0,8 $2(-4,3) \mathrm{cm}$ compr., cilíndricos, desprovidos de aurículas. Capitulescência paniculiforme de cimas corimbiformes, laxas. Capítulos homógamos, discoides; pedúnculos 5-15 mm compr., pubescentes. Invólucro 6-7 × 5,8-6,5 $\mathrm{mm}$, caliculado; brácteas do calículo ca. 4,3 mm compr., linear-lanceoladas; brácteas involucrais 13, oblongas, ápice agudo, piloso, margem escariosa, dorso glabro; eixo da inflorescência plano, alveolado. Flores 20, corola 6,5-7 $\mathrm{mm}$ compr., 5-lobulada, lóbulos 1,5-2 mm compr., anteras ca. $2 \mathrm{~mm}$ compr., base obtusa, apêndice do conectivo ca. 0,5 mm compr., oblongo; estilete ca. $7 \mathrm{~mm}$ compr. Cipselas 2-3 mm compr., cilíndricas, 8-costeladas, seríceo-pubescentes; pápus 5-6 mm compr., caduco.

Material selecionado: entre Diamantina e Conselheiro Mata, 1.180 m, 18¹7'43"S, 4350'34"W, 8.VII.2001, V.C. Souza et al. 25426 (BHCB, CESJ, ESA, RB). 1.300 m, 18 $17^{\prime}$ 'S, 43ํ5' 'W, 18.VII.1987, R. Mello-Silva \& J.R. Pirani CFCR 11055 (SPF). Santo Antônio do Itambé, 9.VIII.1971, G. Hatschbach 30116 (MBM, isótipo).

Endêmica de Minas Gerais, ocorrendo exclusivamente no Planalto de Diamantina, entre os limites de Diamantina e Santo Antônio de Itambé, entre 1.300 a 2.000 m.s.m. Fértil de maio a dezembro. 
Senecio hatschbachii pertence à seção Cacaliastrum (Cabrera 1957) e tem como espécie morfologicamente afim S. macrotis, diferindo desta pelas folhas ovado-elípticas, concolores cinéreas (versus folhas lirado-pinatissectas, distintamente discolores, verde na face adaxial e alvacenta na abaxial), pecíolos sem aurículas (versus pecíolos auriculados na base) e pelas cipselas seríceopubescentes (versus cipselas papilosas).

8.14 Senecio icoglossus DC., Prodr. 6: 420. 1837.

Fig. $2 \mathrm{t}$

Ervas eretas, perenes, 0,25-2 $\mathrm{m}$ alt. Caule multisulcado, fistuloso, densamente folhoso na porção basal, laxamente folhoso na porção apical, glabrescente. Folhas basais com lâmina 14-43 $\times$ 2-15 cm, inteira, elíptica a elíptico-lanceolada, ápice agudo, base atenuada, margem inteira a dentado-crenada, dentes apiculados, pilosa apenas na nervura mediana em ambas as faces, peninérvea; pecíolos 5-16 cm compr., alados, invaginantes na base, aurículas ausentes, glabros. Folhas apicais com lâmina 2,5-8 × 0,2-1,5 cm, inteira, lanceolada, ápice agudo, base decorrente, margem inteira, glabra na face adaxial, glabrescente na face abaxial, peninérvea, sésseis. Capitulescência paniculado-corimbiforme, congesta. Capítulos heterógamos, radiados; pedúnculos 5-35 mm compr., glabrescentes; bractéolas 4-15 mm compr., lanceoladas, glabrescentes. Invólucro 11-14 × 11-14 mm, caliculado; brácteas do calículo 7, 4-5 mm compr., lanceoladas; brácteas involucrais 21, lanceoladas, ápice agudo, piloso, margem escariosa, dorso hirsuto; eixo da inflorescência plano, alveolado. Flores do raio 13, corola lilás, tubo ca. $4 \mathrm{~mm}$ compr., limbo ca. $16 \times 3-3,5 \mathrm{~mm}$, 6-7-nervada, ápice 2-3-dentado; estilete ca. 7 $\mathrm{mm}$ compr., ramos do estilete ca. 1,5 mm compr. Flores do disco 60-65, corola 7,5-8 mm compr., 5-lobulada, lóbulos ca. 1,5 mm compr., anteras ca. 2 mm compr., base obtusa, apêndice do conectivo ca. 0,5 mm compr., oblongo; estilete ca. $8 \mathrm{~mm}$ compr., ramos do estilete $1-1,5 \mathrm{~mm}$ compr. Cipselas $2-3$ $\mathrm{mm}$ compr., cilíndricas, 10-costeladas, glabras; pápus 6-7,5 $\mathrm{mm}$ compr., persistente.

Material selecionado: Alto Caparaó, Parque Nacional do Caparaó, 23.XI.2006, A.M. Teles et al. 297 (BHCB). 26.VIII.1999, J.R. Stehmann et al. 2585 (BHCB, CESJ). Monte Verde, 21.VIII.2001, L.D. Meireles et al. 461 (BHCB, UEC). Camanducaia, 19.XI.1979, H.F. Leitão Filho et al. 10674 (UEC).

Ocorre na Argentina, Paraguai e Brasil. No Brasil, presente em Minas Gerais, Paraná, Rio de
Janeiro, Santa Catarina, Rio Grande do Sul e no Distrito Federal, onde ocorre em brejos de altitude, de 1.900-2.700 m.s.m. Fértil de agosto a janeiro.

Cabrera (1957) reconheceu três variedades, a variedade típica, bem como $S$. icoglossus DC. var. splendens Cabrera e $S$. icoglossus DC. var. gigantophyllus Cabrera. As três variedades diferem entre si pelo indumento que reveste a planta, tamanho das folhas e tamanho do invólucro. Dentre o material examinado, apenas o espécime H.F. Leitão Filho et al. 10674 (UEC) corresponde à Senecio icoglossus var. gigantophyllus, sendo o restante pertencente à variedade típica.

Senecio icoglossus tem como espécie morfologicamente afim $S$. erisithalifolius, que difere de S. icoglossus por possuir as folhas basais com lâmina pinatissecta, enquanto que $S$. icoglossus possui todas as folhas com lâmina inteira ou somente dentado-crenadas Essas são as duas únicas espécies de Senecio ocorrentes em Minas Gerais com flores do raio lilases.

8.15 Senecio lanifer Mart. ex C. Jeffrey, Kew Bull. 47: 96. 1992.

Ervas eretas, perenes, 0,5-1 m alt. Caule multisulcado, meduloso, esparsamente folhoso por toda a extensão, laxamente lanuginoso, indumento persistente. Folhas com lâmina $2-9 \times 0,3-0,6 \mathrm{~cm}$, inteira, lanceolada a oblongo-lanceolada, ápice agudo, base truncada, margem inteira, nervuras imersas, laxamente lanuginosa na face adaxial, densamente lanuginosa na face abaxial, peninérvea, sésseis. Capitulescência corimbiforme, laxa. Capítulos heterógamos, radiados; pedúnculos 3-13 mm compr., lanuginosos; bractéolas 6-10 $\mathrm{mm}$ compr., lanceoladas, lanuginosas. Invólucro 6-9 × 4-8 mm, caliculado; brácteas do calículo 20 , 4-5 mm compr., lanceoladas; brácteas involucrais 20, lanceoladas, ápice agudo, glabro, margem escariosa, dorso glabro; eixo da inflorescência plano, alveolado. Flores do raio 10-12, corola amarela, tubo ca. 3,5 mm compr., limbo 5,5-6 $\times$ ca. $2 \mathrm{~mm}, 5$-nervada, ápice 3-dentado; estilete 5-5,5 mm compr., ramos do estilete ca. 1,5 mm compr. Flores do disco 50, corola 5-6 mm compr., 5-lobulada, lóbulos ca. 1,5 mm compr., anteras ca. 1 $\mathrm{mm}$ compr., base obtusa, apêndice do conectivo ca. $0,3 \mathrm{~mm}$ compr., oblongo; estilete ca. $6 \mathrm{~mm}$ compr., ramos do estilete ca. $1 \mathrm{~mm}$ compr. Cipselas 1-1,5 mm compr., cilíndricas a obcônicas, 10-costeladas, glabras; pápus 4-6 mm compr., persistente.

Material examinado: Entre Sítio e Barbacena, 23.VI.1879, Glaziou 11055 (BHCB). Carandaí, 5.I.1965, 
A.P. Duarte 8696 (BHCB, RB). Poços de Caldas, 6.II.1965, M. Emmerich 2329 (RB).

Ocorre em Minas Gerais, Paraná, São Paulo e Santa Catarina. Em Minas Gerais, a espécie é rara, conhecida por coletas antigas no Campo das Vertentes e sul de Minas Gerais. Fértil de janeiro a junho.

Senecio lanifer pertence à seção Corymbocephalus subseção Simplices (Cabrera 1957) e tem como espécies morfologicamente afins S. nemoralis e S. altimontanus, porém difere destas por possuir as folhas densamente lanuginosas na face abaxial e 20 brácteas involucrais, enquanto que as duas últimas possuem folhas glabras e 10-15 brácteas involucrais.

Iconografia em Cabrera \& Klein (1975: 161, est. 44 i-1).

8.16 Senecio leptoschizus Bong., Mém. Acad. Imp. Sci. St.-Pétersbourg, Sér. 6, Sci. Math. 6(2): 39. 1838.

Fig. $2 \mathrm{u}$

Ervas eretas, perenes, 0,5-1 $\mathrm{m}$ alt. Caule multisulcado, fistuloso, densamente folhoso na porção basal, laxamente folhoso na porção apical, glabro. Folhas com lâmina $6-8 \times 1,5-3$ $\mathrm{cm}$, pinatissecta, segmentos $15-30 \times$ ca. 0,5 $\mathrm{mm}$, filiformes, ápice agudo, margem inteira, uninérveos, glabra em ambas as faces, sésseis. Capitulescência corimbiforme, congesta. Capítulos homógamos, discoides; pedúnculos 3-16 mm compr., glabros; bractéolas 2-3 mm compr., linear-lanceoladas, glabras. Invólucro ca. $8 \times 4$ $\mathrm{mm}$, caliculado; brácteas do calículo 3 , linearlanceoladas, ca. $2 \mathrm{~mm}$ compr.; brácteas involucrais 8, oblongas, ápice agudo, piloso, margem escariosa, dorso glabro; eixo da inflorescência plano, alveolado. Flores 10-12, corola 6,5-7 mm compr., 5-lobulada, lóbulos ca. $2 \mathrm{~mm}$ compr., anteras ca. $2 \mathrm{~mm}$ compr., base obtusa, apêndice do conectivo ca. 0,5 mm compr., oblongo; estilete ca. $8 \mathrm{~mm}$ compr., ramos do estilete ca. $2 \mathrm{~mm}$ compr. Cipselas 1-1,5 mm compr., cilíndricas, 10-costeladas, seríceo-pubescentes; pápus 6-7 mm compr., caduco.

Material examinado: Aiurouca, 22.I.1886, Glaziou 16147 (BHCB). Poços de Caldas, 1845, Widgren 214 (BHCB). Retiro Branco, 7.II.1975, O. Roppa 549 (RB).

Ocorre em Minas Gerais, Paraná, Santa Catarina e São Paulo. Em Minas Gerais, é rara, conhecida apenas por coletas antigas no sul desse estado. Fértil em janeiro e fevereiro.

Senecio leptoschizus pertence à seção Corymbocephalus subseção Brasilienses (Cabrera
1957) e tem como espécies morfologicamente afins S. brasiliensis e $S$. linearilobus. Difere da primeira pelos segmentos foliares com no máximo $1 \mathrm{~mm}$ larg. (versus 1,5-7 mm larg.) e de $S$. linearilobus por possuir capítulos discoides, enquanto esta espécie possui capítulos radiados.

8.17 Senecio linearilobus Bong., Mém. Acad. Imp. Sci. St.-Pétersbourg, Sér. 6, Sci. Math. 6(2): 37. 1838 .

Ervas a arbustos eretos, perenes, 0,3-1,2 $\mathrm{m}$ alt. Caule multisulcado, meduloso, desamente folhoso na porção basal, esparsamente folhoso na porção apical, glabro. Folhas com lâmina 4-9 × 1,5-2,5 cm, pinatissecta, segmentos 6-10 pares, $10-20 \times 0,5-1$ $\mathrm{mm}$, lineares, margem inteira, glabra em ambas as faces, uninérveos, sésseis. Capitulescência corimbiforme, laxa. Capítulos heterógamos, radiados; pedúnculos 4-14 mm compr., glabros; bractéolas lanceoladas, ca. $2 \mathrm{~mm}$ compr., ciliadas. Invólucro 5-7 × 5-6 mm, caliculado; brácteas do calículo 4, lanceoladas, ca. 2 mm compr.; brácteas involucrais 10-12, lanceoladas, ápice agudo, piloso, margem escariosa, dorso glabro; eixo da inflorescência plano, alveolado. Flores do raio 4-6, corola amarela, tubo ca. 3,5 mm compr., limbo ca. $7 \times 3,5 \mathrm{~mm}, 4$-nervada, ápice 3-dentado; estilete ca. $5 \mathrm{~mm}$ compr., ramos do estilete ca. 1,5 $\mathrm{mm}$ compr. Flores do disco 12, corola 6,5-7 $\mathrm{mm}$ compr., 5-lobulada, lóbulos ca. 1,5 mm compr., anteras ca. $2 \mathrm{~mm}$ compr., base obtusa, apêndice do conectivo ca. $0,5 \mathrm{~mm}$ compr., oblongo; estilete ca. $6 \mathrm{~mm}$ compr., ramos do estilete ca. 1,5 mm compr. Cipselas 1,5-2,5 mm compr., cilíndricas, 10-costeladas, seríceo-tomentosas; pápus 4-6 mm compr., persistente.

Material selecionado: Moeda, $1.560 \mathrm{~m}, 20^{\circ} 20^{\prime} 9,4$ "'S, 4356'17,1"W, 26.IV.2007, A.M. Teles et al. 443 (BHCB). Ouro Preto, $1.904 \mathrm{~m}, 20^{\circ} 12^{\prime} 35,5^{\prime} \mathrm{S}$, 433'27,5”W, 11.VII.2007, A.M. Teles et al. 467 (BHCB). Santa Bárbara, $1.637 \mathrm{~m}, 20^{\circ} 03^{\prime} 24$ "S, 4341'28,6"W, 26.XII.2007, F.F. Carmo 1514 (BHCB).

Ocorre em Minas Gerais e Paraná. Em Minas Gerais, é rara, conhecida do quadrilátero ferrífero, em campos ferruginosos, entre 1.250 a 1.904 m.s.m. Fértil de dezembro a agosto.

Senecio linearilobus pertence à seção Corymbocephalus subseção Brasilienses (Cabrera 1957) e tem como espécie morfologicamente afim S. leptoschizus. Difere desta por possuir capítulos radiados e 10-12 brácteas involucrais, enquanto que $S$. leptoschizus possui capítulos discoides e 8 brácteas involucrais. 
8.18 Senecio macrotis Baker, Fl. bras. 6(3): 308. 1884.

Fig. $2 \mathrm{v}$

Ervas robustas ou arbustos, eretos, perenes, 1-2,5 m alt. Caule multisulcado, fistuloso, densamente folhoso por toda a extensão, densamente albo-tomentosos. Folhas com lâmina 15-26 × 6-13,5 cm, lirado-pinatissecta, discolor, verde na face adaxial e alvacenta na face abaxial, lóbulo terminal oblongo-ovado, ápice agudo, base arredondada, margem irregularmente denteada, dentes agudos, 1-3 pares de lóbulos opostos, oblongos, ápice obtuso, ca. $3 \times 1,5 \mathrm{~cm}$, laxamente lanosa na face adaxial, densamente albo-tomentosa na face abaxial, peninérvea; pecíolos 3,5-8 cm compr., cilíndricos, auriculados na base, aurículas 1,5-2 × 2-3 cm, reniformes. Capitulescência paniculiforme, laxa. Capítulos homógamos, discoides; pedúnculos 10-15 mm compr., densamente tomentosos; bractéolas 3-3,5 mm compr., lanceoladas, glabras. Invólucro 8-9 $\times$ 5-10 mm, caliculado; brácteas do calículo 4, 2-3 $\mathrm{mm}$ compr., linear-lanceoladas, lanosas; brácteas involucrais 8-13, lanceoladas, ápice agudo, piloso, margem escariosa, dorso glabro; eixo da inflorescência plano, alveolado. Flores 10-30, corola 6,5-7 mm compr., 5-lobulada, lóbulos 1,5-2 mm compr., anteras ca. $2 \mathrm{~mm}$ compr., base sagitada, apêndice do conectivo ca. $0,5 \mathrm{~mm}$ compr., oblongo; estilete ca. $7 \mathrm{~mm}$ compr., ramos do estilete ca. 2 $\mathrm{mm}$ compr. Cipselas $2-2,5 \mathrm{~mm}$ compr., cilíndricas, 10-costeladas, papilosas; pápus ca. $7 \mathrm{~mm}$ compr., caduco.

Material selecionado: Santana do Riacho, 14.VIII, 1992, M. Pereira \& M. Lucca 856 (BHCB). Santo Antônio do Itambé, 5.X.2006, A.M. Teles et al. 251 (BHCB). São Gonçalo do Rio Preto, 1.320 m, $18^{\circ} 12^{\prime} 04^{\prime \prime} \mathrm{S}, 43^{\circ} 20^{\prime} 19,7^{\prime}$ 'W, 2.IV.2004, P.L. Viana et al. 1711 (BHCB).

Cabrera (1957) citou a espécie unicamente para Minas Garais, especificamente para a localidade típica, a Serra do Cipó. No entanto, Teles \& Stehmann (2008) registraram-na também para a Bahia. Em Minas Gerais, além da localidade típica, é conhecida para Santo Antônio do Itambé e São Gonçalo do Rio Preto, em campo rupestre. No Pico do Itambé forma grandes populações, ocupando extensas áreas. Fértil de agosto a abril.

Senecio macrotis pertence à seção Cacaliastrum (Cabrera 1957) e tem como espécie morfologicamente afim $S$. hatschbachii, porém difere desta por possuir folhas com lâmina liradopinatissecta, distintamente discolor, pecíolos com um par de aurículas na base e cipselas papilosas, enquanto que $S$. hatschbachii possui folhas com lâmina ovado-elíptica, concolor, pecíolos sem aurículas e cipselas pubescentes.

8.19 Senecio nemoralis Dusén, Arch. Mus. Nac. Rio de Janeiro 13: 21. $1903 . \quad$ Fig. 2w

Arbustos eretos, perenes, 1-1,5 m alt. Caule levemente estriado, meduloso, folhoso por toda a extensão, glabro. Folhas com lâmina 2-10 × 0,5-0,8 $\mathrm{cm}$, inteira, lanceolada, ápice agudo, acuminado, base atenuada, levemente auriculada, margem irregularmente serreada, plana, glabra em ambas as faces, peninérvea, sésseis. Capitulescência corimbiforme, laxa. Capítulos heterógamos, radiados; pedúnculos 15-30 mm compr., glabros; bractéolas lanceoladas, 1-5 mm compr., glabros. Invólucro 8-10 × 5-6 mm, caliculado; brácteas do calículo 5, lanceoladas, 3-4 mm compr.; brácteas involucrais $12-15$, lanceoladas, ápice agudo, glabro, margem escariosa, dorso glabro; eixo da inflorescência plano, alveolado. Flores do raio 7-8, corola amarela, tubo 4,5-5 mm compr., limbo ca. $9 \times 2,5 \mathrm{~mm}, 4-5$-nervada, ápice 3-dentado; estilete ca. $6 \mathrm{~mm}$ compr., ramos do estilete ca. 1,5 $\mathrm{mm}$ compr. Flores do disco 50, corola ca. $9 \mathrm{~mm}$ compr., 5-lobulada, lóbulos 1-1,2 mm compr., hirsutos internamente, anteras ca. 2,5 mm compr., base obtusa, apêndice do conectivo ca. 0,2 mm compr., oblongo; estilete ca. $9 \mathrm{~mm}$ compr., ramos do estilete ca. 1,5 mm compr. Cipselas 3-4 mm compr., cilíndricas, 10-costeladas, hirsutas entre as costelas; pápus 4-7 $\mathrm{mm}$ compr., persistente.

Material examinado: Alagoa, $2.376 \mathrm{~m}, 22^{\circ} 12^{\prime} 14^{\prime \prime}$, $44^{\circ} 45^{\prime} 36^{\prime \prime} \mathrm{W}, 10 . \mathrm{XI} .2007$, P.L. Viana et al. 3265 (BHCB). $1.950 \mathrm{~m}, 22^{\circ} 12^{\prime} 42,2^{\prime \prime} \mathrm{S}, 44^{\circ} 45^{\prime} 11,5^{\prime \prime} \mathrm{W}, 11 . \mathrm{XII} .2007$, A. Salino et al. 12964 (BHCB). Itamonte, $2.150 \mathrm{~m}$, $22^{\circ} 17^{\prime} 38^{\prime \prime}$, $44^{\circ} 45^{\prime} 01^{\prime \prime} \mathrm{W}, 7 . X \mathrm{XI} 2007$, N.F.O. Mota et al. 943 (BHCB).

Senecio nemoralis é citada pela primeira vez para Minas Gerais. Cabrera (1957) registrou a espécie como endêmica do Rio de Janeiro, no Itatiaia, porém, no presente estudo examinaram-se materiais procedentes dos municípios de Alagoa, Itamonte e Poços de Caldas, em Minas Gerais. Rara em Minas Gerais, é comum na Serra do Itatiaia, sendo provavel que ocorra na vertente mineira desta serra, pois há registros de coleta da espécie na região do abrigo Rebouças, uma área do Parque limítrofe entre os estados de Rio de Janeiro e Minas Gerais. Ocorre em campos de altitude, de 1.950 a 2.376 m.s.m. Fértil de novembro a fevereiro.

Senecio nemoralis pertence à seção Corymbocephalus subseção Simplices (Cabrera 
1957). Tem como espécie morfologicamente afim $S$. altimontanus, porém difere por possuir folhas com lâmina lanceolada, de base levemente auriculada, flores do raio 7-8 e cipselas hirsutas, enquanto que $S$. altimontanus possui folhas com lâmina oblanceolada, de base atenuada e sem aurículas, flores do raio 12-14 e cipselas glabras.

8.20 Senecio oleosus Vell., Fl. Flum., Icon. 8: 104. 1831(1827).

Fig. $2 \mathrm{x}$

Ervas anuais, bianuais ou perenes, rizomatosas, 0,25-1,5 $\mathrm{m}$ alt. Caule estriado, fistuloso, folhoso por toda a extensão, densamente pubescente-glanduloso. Folhas basais rosuladas, lâmina 4-13 × 1-3 cm, inteira, obovada, ápice agudo, base atenuada, margem serreada, pubescente-glandulosa em ambas as faces, peninérvea, sésseis. Folhas apicais gradativamente menores, lâmina inteira ovado-lanceolada, base auriculada, semi-amplexicaule, margem serreada, peninérvea, sésseis. Capitulescência corimbiforme, congesta. Capítulos heterógamos, radiados; pedúnculos 20-40 mm compr., densamente hirsuto-glandulosos, ebracteolados. Invólucro ca. $10 \times 8-12 \mathrm{~mm}$, caliculado; brácteas do calículo 25 , 5-9 mm compr., linear-lanceoladas, densamente hirsuto-glandulosas; brácteas involucrais 20-21, lanceoladas, ápice agudo, penicelado, margem escariosa, dorso densamente hirsuto-glanduloso; eixo da inflorescência plano, alveolado. Flores do raio 15-21, corola amarela, tubo 4-5,5 $\mathrm{mm}$ compr., limbo 13-14 × 2,5-3 mm, 4-6-nervada, ápice 3-dentado; estilete ca. $6 \mathrm{~mm}$ compr., ramos do estilete ca. $1,5 \mathrm{~mm}$ compr. Flores do disco 60 , corola ca. $7 \mathrm{~mm}$ compr., 5-lobulada, lóbulos ca. $1 \mathrm{~mm}$ compr., anteras ca. $2,5 \mathrm{~mm}$ compr., base obtusa, apêndice do conectivo ca. $0,5 \mathrm{~mm}$ compr., oblongo; estilete ca. $10 \mathrm{~mm}$ compr., ramos do estilete ca. 1,5 mm compr. Cipselas 3-4 mm compr., cilíndricas, 10-costeladas, glabras; pápus 4-8 mm compr., persistente.

Material selecionado: Alagoa, $2.250 \mathrm{~m}, 22^{\circ} 12^{\prime} 18^{\prime \prime} \mathrm{S}$, 4446'1,2"W, 11.XII.2007, A. Salino et al. 12965 (BHCB). Itamonte, $1.869 \mathrm{~m}, 22^{\circ} 17^{\prime} 28^{\prime \prime} \mathrm{S}, 44^{\circ} 45^{\prime} 43^{\prime \prime} \mathrm{W}$, 7.XI.2007, N.F.O. Mota et al. 982 (BHCB). Passa

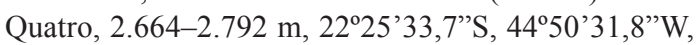
7.VI.2006, L.D. Meireles et al. 2409 (BHCB, UEC).

Hind (1993) citou a espécie como ocorrente nos estados do Rio de Janeiro, São Paulo, Paraná e Santa Catarina. No entanto, examinaram-se materiais provenientes de Alagoa, Itamonte, Ouro Preto e Passa Quatro, em Minas Gerais, registrando-se a espécie pela primeira vez para o estado. Ocorre em campos de altitude, de 1.869 a 2.792 m.s.m. Fértil de novembro a junho.

Senecio oleosus pertence à seção Corymbocephalus subseção Viscosi (Baker) Cabrera (Cabrera 1957). É a única espécie dessa subseção ocorrente em Minas Gerais. Difere das demais espécies de Senecio ocorrentes em Minas Gerais pelo indumento distintamente pubescenteglanduloso, conferindo à planta um aspecto pegajoso.

8.21 Senecio paucijugus Baker, Fl. bras. 6(3): 323. 1884.

Ervas a arbustos eretos, perenes, $1-1,5 \mathrm{~m}$ alt. Caule multisulcado, fistuloso, densamente folhoso por toda a extensão, glabro. Folhas apicais com lâmina ca. $4 \times 0,6 \mathrm{~cm}$, inteira, lanceolada, ápice agudo, base alargada, semi-amplexicaule, margem inteira, glabra em ambas as faces, peninérvea, sésseis; folhas medianas e basais com lâmina 4-12 $\times 0,8-4 \mathrm{~cm}$, pinatissecta, segmentos 1-2-jugos, 10-15 × 0,6-1,2 mm, lanceolados, ápice agudo, base alargada, semi-amplexicaule, margem inteira, glabra em ambas as faces, peninérveo, sésseis. Capitulescência corimbiforme, congesta. Capítulos heterógamos, radiados, pedunculados; pedúnculos glabros; bractéolas lanceoladas, glabras. Invólucro ca. $8 \times 6-7 \mathrm{~mm}$, caliculado; brácteas do calículo lanceoladas; brácteas involucrais 20, oblongas, ápice agudo a obtuso, glabro, margem escariosa, dorso glabro; eixo da inflorescência plano, fimbriado. Flores do raio $8-12$, corola amarela, tubo ca. $6 \mathrm{~mm}$ compr., limbo ca. $7 \times 3 \mathrm{~mm}$, 4-nervada, ápice 3-dentado, estilete 7-8 $\mathrm{mm}$ compr., ramos do estilete ca. 2,5 mm compr. Flores do disco 30, corola 8,5-9 mm compr, 5-lobulada, lóbulos ca. $1 \mathrm{~mm}$ compr., anteras ca. 2,5 mm compr., exsertas, apêndice do conectivo ca. 0,5 mm compr., oblongo-deltoide, base obtusa; estilete $9-9,5 \mathrm{~mm}$ compr., ramos do estilete ca. $2 \mathrm{~mm}$ compr. Cipselas 2,5-3 mm compr., cilíndricas, 8-costeladas, glabras; pápus 5,5-8 mm compr., caduco.

Material examinado: Barbacena, 23.VI.1879, Glaziou 11052 (BHCB). 23.VI.1879, Glaziou 11053 (K, lectótipo; $\mathrm{P}$, isolectótipo).

Baker (1884), Cabrera (1957) e Hind (1993) citaram esta espécie como ocorrente no Rio de Janeiro e Minas Gerais. No entanto, esta espécie é endêmica de Minas Gerais e, até o momento, conhecida apenas pelo material-tipo e por outra coleta realizada no mesmo dia e localidade do tipo. Fértil em junho. 
Senecio paucijugus pertence à seção Corymbocephalus subseção Brasilienses (Cabrera 1957). Tem como espécie morfologicamente afim $S$. brasiliensis, porém difere desta pela capitulescência mais congesta e pelas folhas apicais com lâmina inteira, base alargada e semiamplexicaule (versus folhas apicais com lâmina pinatisecta, base atenuada e não amplexicaule de S. brasiliensis).

8.22 Senecio paulensis Bong., Mém. Acad. Imp. Sci. Saint-Pétersbourg, Sér. 6, Sci. Math., Seconde Pt. Sci. Nat. 6(2): 33. 1838.

Ervas eretas, perenes, $0,5-1,8 \mathrm{~m}$ alt. Caule multisulcado, meduloso, esparsamente folhoso por toda a extensão, glabro. Folhas com lâmina 10-15 $\times 4-5 \mathrm{~cm}$, bipinatissecta, , segmentos 10-20 pares, lobados ou sectados, os primários oblanceolados, 15-30 × 2-11 mm, os secundários espatuliformes, peninérveos, margem inteira, glabra em ambas as faces, sésseis. Capitulescência corimbiforme, congesta. Capítulos heterógamos, radiados; pedúnculos 0,9-5,2 cm compr., hirsutos; bractéolas 2,5-3,5 mm compr., linear-lanceoladas, ciliadas. Invólucro 5-8 × 6-7 mm, caliculado; brácteas do calículo 5, 3-3,5 mm compr., lineares; brácteas involucrais 10-13, lanceoladas, ápice agudo, piloso, margem escariosa, dorso glabro; eixo da inflorescência plano, alveolado. Flores do raio 7 , corola amarela, tubo $4,5-5 \mathrm{~mm}$ compr., limbo 7-8 $\times$ ca. $3 \mathrm{~mm}, 4-5$-nervada, ápice 3-dentado, estilete ca. $7 \mathrm{~mm}$ compr., ramos do estilete ca. $1,5 \mathrm{~mm}$ compr. Flores do disco 30, corola 7-7,5 mm compr, 5-lobulada, lóbulos da corola 1-1,5 mm compr., anteras ca. $2 \mathrm{~mm}$ compr., exsertas, apêndice do conectivo ca. $0,5 \mathrm{~mm}$ compr., oblongo, base obtusa; estilete ca. $7 \mathrm{~mm}$ compr., ramos do estilete ca. 1,5 $\mathrm{mm}$ compr. Cipselas $2-3 \mathrm{~mm}$ compr., cilíndricas, 10-costeladas, seríceo-tomentosas; pápus 4-5 mm compr., caduco.

Material examinado: Camanducaia, 15.III.1976, H.F. Leitão Filho 1858 (UEC). Lima Duarte, 10.II.2001, M.A. Heluey et al. 50 (CESJ). 11.III.2004, R.C. Forzza et al. 3192 (BHCB, RB).

Hind (1993) citou a espécie como ocorrente em São Paulo e Paraná. No entanto, Cabrera \& Klein (1975) citaram-na também para Santa Catarina. Em Minas Gerais foi examinado material da espécie proveniente de Camanducaia e Lima Duarte, registrando-se pela primeira vez a ocorrência para o estado. Fértil em fevereiro e março.

Senecio paulensis pertence à seção Corymbocephalus subseção Brasilienses (Cabrera 1957). Tem como espécie morfologicamente afim
S. brasiliensis, porém difere desta pelas folhas com lâmina bipinatissecta. Assemelha-se ainda a $S$. flaccidus, porém difere desta última pelos segmentos foliares sectados e glabros (versus segmentos foliares lobados e densamente albotomentosos).

Iconografias em Cabrera \& Klein (1975: 176, est. 49 a-b, : 178, est. 50).

8.23 Senecio pohlii Sch. Bip. ex Baker, Fl. bras. 6(3): 303. 1884.

Ervas eretas, perenes, 1-1,5 m alt. Caule multisulcado, meduloso, densamente folhoso na porção basal, laxamente folhoso na porção apical, pubescente. Folhas basais com lâmina 3-17,5 $\times 0,5-3 \mathrm{~cm}$, interia, lanceolada, ápice agudo, base atenuada, margem serreada, ciliada, dentes agudos, glabra na face adaxial, pubescente na face abaxial, peninérvea, sésseis. Folhas apicais com lâmina 0,6-6×0,2-1 cm, inteira, lanceolada, ápice agudo, base atenuada, margem serreada, dentes agudos, glabra na face adaxial, pubescente na face abaxial, sésseis. Capitulescência corimbiforme, laxa. Capítulos homógamos, discoides; pedúnculos 2-70 mm compr., pubescentes; bractéolas 3-4 mm compr., lanceoladas, pubescentes. Invólucro 6-12× 4-9 mm, caliculado; brácteas do calículo 4, 2,5-5 mm compr., lanceoladas; brácteas involucrais 9-20, oblongas, ápice agudo, piloso, margem escariosa, dorso glabro; eixo da inflorescência plano, alveolado. Flores 40-50, corola ca. 8,5 mm compr., 5-lobulada, lóbulos ca. 0,5 mm compr., anteras ca. 2 mm compr., base obtusa, apêndice do conectivo ca. $0,5 \mathrm{~mm}$ compr., oblongo; estilete ca. $8 \mathrm{~mm}$ compr., ramos do estilete $1-1,5 \mathrm{~mm}$ compr. Cipselas $1-1,5$ $\mathrm{mm}$ compr., cilíndricas, 10 -costeladas, seríceas; pápus 5-7 mm compr., caduco.

Material selecionado: Catas Altas, 4.IV.2007, A.M. Teles et al. 374 (BHCB, S). Itacambira, Moeda, 1.450 m, 20¹9'28"S, 4356'24"W, 9.V.2007, F.F. Carmo 597 (BHCB). Ouro Preto, 12.VII.2007, A.M. Teles et al.

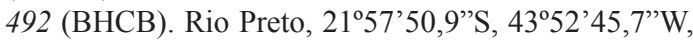
10.IV.2007, A.M. Teles et al. 401 (BHCB).

Ocorre em Goiás, Minas Gerais e São Paulo. Em Minas Gerais, ocorre em áreas de cerrado, campos rupestres, campos de altitude, áreas brejosas e em áreas perturbadas. Fértil de dezembro a julho.

Senecio pohlii pertence à seção Corymbocephalus subseção Simplices (Cabrera 1957). Tem como espécie afim S. emiliopsis, porém conforme comentado em S. emiliopsis, segundo Baker (1884) e Cabrera (1957) a única diferença entre as duas espécies é o indumento 
tomentoso presente na face abaxial das folhas de S. emiliopsis. Senecio pohlii é uma espécie muito variável morfologicamente, especialmente no tamanho e forma dos capítulos, que podem possuir invólucro largamente a estreitamente campanulado, quase cilíndrico. As popupulações encontradas na Serra do Caraça, especialmente no Pico do Inficcionado (R.C. Mota 120 (BHCB); A.M. Teles et al. 374, 376 e 384 (BHCB); M.F. Vasconcelos s.n., BHCB 52766), na Serra da Piedade (T.S.M. Grandi et al. s.n., BHCB 1080; J.A. Lombardi 1250 (BHCB)), na Serra da Moeda (F.F. Carmo 163 (BHCB)) e na Serra de Capanema (F.F. Carmo 297 (BHCB); A.M. Teles et al. 492 (BHCB)), apresentam um extremo de variação morfológica da espécie. Estes espécimes apresentam menor porte, capítulos menores e mais delicados e flores vináceas, assemelhandose à S. pseudopohlii Cabrera, espécie descrita por Cabrera (1957) e posteriormente sinominizada por Hind (1993) sob S. pohlii. Já espécimes da população encontrada na Serra do Funil, no município de Rio Preto [F.R.G. Salimena et al. 1244 (CESJ); P.L. Viana \& N.F.O. Mota 1975 (BHCB); C.N. Matozinhos et al. 174 (CESJ); A.M. Teles et al. 401 (BHCB)] apresentam outro extremo de variação, com um porte maior e capítulos muito ampliados, com invólucro mais campanulado e flores alvacentas. Entre esses dois extremos de variação está a maioria dos exemplares examinados, havendo uma nítida gradação morfológica, não sendo possível estabelecer uma faixa clara para circunscrever unidades taxonômicas distintas. Os espécimes com variações intermediárias apresentam flores com coloração lilás. É possível que se trate de uma espécie naturalmente polimórfica e que as populações encontradas no alto de montanhas representem extremos de variação morfológica.

Iconografia em Teles \& Stehmann (2011, p. 67, fig. 4).

8.24 Senecio pseudostigophlebius Cabrera, Bol. Soc. Argent. Bot. 7: 245. $1959 . \quad$ Fig. 2y

Ervas eretas, perenes, 0,5-1 m alt. Caule estriado, meduloso, folhoso por toda a extensão, laxamente tomentoso. Folhas com lâmina 10-15 $\times$ 3,5-4 cm, pinatipartida, ápice obtuso, base atenuada, conspicuamente auriculada, 5-8 pares de segmentos obtusos, lóbulos $0,7-2 \times$ 0,6-1,7 cm, margem sinuada, pubescente na face adaxial, densamente albo-tomentosa na face abaxial, peninérvea, sésseis. Capitulescência corimbiforme, laxa. Capítulos heterógamos, radiados; pedúnculos 5-15 mm compr., tomentosos; bractéolas $4 \mathrm{~mm}$ compr., lanceoladas, tomentosas. Invólucro 6-9 × 6-7 mm, caliculado; brácteas do calículo 4, 3,5-4 mm compr., lanceoladas; brácteas involucrais 8, oblongas, ápice agudo, lanuginoso, margem escariosa, dorso glabro; eixo da inflorescência plano, alveolado. Flores do raio 6-10, corola amarela, tubo 3-4 mm compr., limbo 10-11 × 1-2,5 mm, 4-nervada, ápice 3-dentado; estilete ca. $8 \mathrm{~mm}$ compr., ramos do estilete ca. $2 \mathrm{~mm}$ compr. Flores do disco 25, corola ca. $7 \mathrm{~mm}$ compr., 5-lobulada, lóbulos ca. $1 \mathrm{~mm}$ compr.; anteras ca. 2,5 mm compr., base obtusa, apêndice do conectivo ca. $0,5 \mathrm{~mm}$ compr., oblongo; estilete ca. $8 \mathrm{~mm}$ compr., ramos do estilete ca. 1,7 mm compr. Cipselas ca. 2,5 mm compr., cilíndricas, 10-costeladas, glabras; pápus 6-7 mm compr., persistente.

Material examinado: Passa Quatro, 1.974-2.037 m, 10.VIII.2005, L.D. Meireles \& J.A. Nunes 1958 (BHCB, UEC). $2.463 \mathrm{~m}, 22^{\circ} 25$ '3,9”S, 4448'54,6"W, 31.VIII.2007, L.D. Meireles et al. 3310 (BHCB, UEC).

Espécie considerada por Cabrera (1957, 1959) e Hind (1993) como endêmica do estado do Rio de Janeiro. No entanto, examinamos material da espécie proveniente de Passa Quatro, Minas Gerais, registrando pela primeira vez a ocorrência da espécie para o estado. Habita os campos de altitude, entre 1.970 e 2.500 m.s.m. Fértil em agosto.

Senecio pseudostigophlebius pertence à seção Adamantina (Cabrera 1957) e tem como espécies morfologicamente mais similares $S$. colpodes e $S$. adamantinus. Diferencia-se da primeira pelas brácteas involucrais em número de 8 e pela margem foliar profundamente pinatilobada ou pinatipartida, enquanto que S. colpodes possui 10-15 brácteas involucrais e lâmina foliar com margem apenas crenadolobada. Diferencia-se ainda de S. adamantinus pela margem foliar pinatilobada ou pinatipartida (versus inteira, lobada ou denteada) e por possuir 6-10 flores do raio, enquanto $S$. adamantinus possui 2-3.

Cabrera (1959) esclareceu o equívoco cometido por ele mesmo, em 1957, pois na revisão das espécies de Senecio do Brasil, Paraguai e Uruguai, a espécie, cuja descrição é apresentada sob o epíteto específico de S. stigophlebius, na verdade corresponde a uma espécie nova, somente descrita em 1959 e à qual nomeou de $S$. pseudostigophlebius. 
8.25 Senecio stigophlebius Baker, Fl. bras. 6(3): 321. 1884.

Fig. $2 \mathrm{z}$

Arbustos eretos, perenes, 2-4 m alt. Caule multisulcado, fistuloso, folhoso por toda a extensão, lanuginoso ou glabro. Folhas com lâmina 20-35 × 12-20 cm, lirado-pinatissecta, elíptica ou obovado-elíptica, 4-7 pares de segmentos, $6-12 \times 2-3 \mathrm{~cm}$, lanceolados ou oblongos, ápice agudo, margem irregularmente denteada, dentes agudos, lanuginosa ou glabra na face adaxial, densamente albo-tomentosa na face abaxial, peninérvea, nervuras proeminentes; pecíolos 5-10 cm compr., cilíndricos, auriculados na base, aurículas semi-circulares, amplexicaules. Capitulescência corimbiforme, congesta. Capítulos heterógamos, radiados; pedúnculos 10-30 mm compr., albo-tomentosos; bractéolas 3-4 mm compr., lanceoladas, albo-tomentosas. Invólucro 10-12 × ca. $6 \mathrm{~mm}$, caliculado; brácteas do calículo 4, 4-5 mm compr., lanceoladas; brácteas involucrais 12-14, oblongas, ápice agudo, glabro, margem escariosa, dorso glabro; eixo da inflorescência plano, alveolado. Flores do raio 10, corola amarela, tubo ca. $4 \mathrm{~mm}$ compr., limbo 12-138 × ca. $2 \mathrm{~mm}$, 4-nervada, ápice 3-dentado; estilete ca. $8 \mathrm{~mm}$ compr., ramos do estilete ca. 2 $\mathrm{mm}$ compr. Flores do disco 15-20, corola ca. 8 mm compr., 5-lobulada, lóbulos ca. $2 \mathrm{~mm}$ compr., anteras ca. 2,5 mm compr., base obtusa, apêndice do conectivo ca. $0,5 \mathrm{~mm}$ compr., oblongo; estilete ca. $9 \mathrm{~mm}$ compr., ramos do estilete ca. $2,5 \mathrm{~mm}$ compr. Cipselas 2,5-4 mm compr., obcônicas a cilíndricas, 8-costeladas, glabras; pápus $6-7 \mathrm{~mm}$ compr., persistentes.

Material examinado: Camanducaia, 23.VIII.2001, L.D. Meireles et al. 532 (BHCB, UEC). Itamonte,

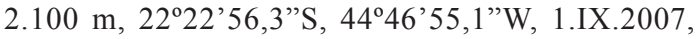
L.D. Meireles et al. 3316 (BHCB, UEC). Passa Quatro, $2.254 \mathrm{~m}, 22^{\circ} 26^{\prime} 6,2^{\prime \prime} \mathrm{S}, 44^{\circ} 53^{\prime} 19^{\prime \prime} \mathrm{W}, 12 . \mathrm{IX} .2006$, L.D. Meireles et al. 2568 (BHCB, UEC).

Ocorre em Minas Gerais, Rio de Janeiro, São Paulo, Paraná e Santa Catarina. Senecio stigophlebius é citada pela primeira vez para Minas Gerais, onde foi coletada em subosque de capões, nos campos de altitude da Serra da Mantiqueira, em Camanducaia, Itamonte e Passa Quatro, entre 2.100 e 2.254 m.s.m. Fértil de agosto a novembro.

\section{Agradecimentos}

Aos curadores dos herbários consultados. Ao $\mathrm{CNPq}$, a bolsa de produtividade em pesquisa concedida ao segundo autor.

\section{Referências}

Baker, J.G. 1884. Compositae IV: Helianthoideae Mutisiaceae. In: Martius, C.F.P. \& Eichler, A.G. (eds.). Flora Brasiliensis. Monachii, Lipsiae. Vol. 6, pars 3, pp.135-398.

Barkley, T.M. 1985. Infrageneric groups in Senecio, s.l., and Cacalia, s.l. (Asteraceae: Senecioneae) in Mexico and Central America. Brittonia 37: 211-218.

Barroso, G.M. 1957. Flora do Itatiaia - Compositae. Rodriguésia 20: 171-241.

Belcher, R.O. 1956. A revision of the genus Erechtites (Compositae), with inquiries into Senecio and Arrhenechthites. Annals of the Missouri Botanical Garden 43: 1-85.

BFG. 2015. Growing knowledge: an overview of Seed Plant diversity in Brazil. Rodriguésia 66: 1085-1113.

Bremer, K. 1994. Asteraceae: cladistics and classification. Timber Press, Portland. 752p.

Bridson, D. \& Forman, L. 1992. The herbarium handbook. Richmond. Royal Botanic Gardens, Kew. 346p.

Cabrera, A.L. 1950. Notes on the Brazilian Senecioneae. Brittonia 7: 53-74.

Cabrera, A.L. 1957. El genero Senecio (Compositae) en Brasil, Paraguay y Uruguay. Arquivos do Jardim Botânico do Rio de Janeiro 15: 163-264.

Cabrera, A.L. 1959. Notas sobre tipos de Compuestas sudamericanas en herbarios Europeos I. Boletin de la Sociedad Argentina de Botanica 7: 233-246.

Cabrera, A.L. 1974. Compositae. In: Burkart, A. (ed.). Flora Ilustrada de Entre Rios (Argentina) 6: 106-540.

Cabrera, A.L. 1978. Compositae. In: Cabrera, A.L. (ed.). Flora de la Provincia de Jujuy - Republica Argentina 10: 1-726.

Cabrera, A.L. \& Klein, R.M. 1975. Compostas - Tribo: Senecioneae. In: Reitz, R. (ed.). Flora Ilustrada Catarinense 2: 126-222.

Filgueiras, T.S.; Brochado, A.L.; Nogueira, P.H. \& Guala II, G.F. 1994. Caminhamento - um método expedito para levantamentos florísticos qualitativos. Cadernos de Geociências. 12: 39-43.

Frodin, D.G. 2004. History and concepts of big plant genera. Taxon 53: 753-776.

Greenman, J.M. 1902. Monographie der Nordund Centralamerikanischen Arten der Gattung Senecio. Botanische Jahrbücher für Systematik, Pflanzengeschichte und Pflanzengeographie 32: 1-33.

Hind, D.J.N. 1992. Plant Portraits: 205. Pseudogynoxys cabrerae. Compositae. Kew Magazine 9: 153-156.

Hind, D.J.N. 1993. A checklist of the Brazilian Senecioneae (Compositae). Kew Bulletin 48: 279-295. 
Hind, D.J.N. 1999. The tribe Senecioneae (Compositae) in Bahia, Brazil, with descriptions of a new section and species in Senecio. Kew Bulletin 54: 897-904.

Jeffrey, C. 1992. The tribe Senecioneae (Compositae) in the Mascarene Islands with an annotated world check-list of the genera of the tribe. Notes on Compositae: VI. Kew Bulletin 47: 49-109.

Jeffrey, C.; Halliday, P.; Wilmot-Dear, M. \& Jones, S.W. 1977. Generic and sectional limits in Senecio (Compositae): I. Progress report. Kew Bulletin 32: 47-67.

Matzenbacher, N.I. 1996. Duas novas espécies e uma nova forma do gênero Senecio L. (Asteraceae - Senecioneae) no Rio Grande do Sul - Brasil. Comunicações do Museu de Ciências e Tecnologia - PUCRS. Série Botânica 2: 3-14.

Matzenbacher, N.I. 1998. O complexo "Senecionóide" (Asteraceae - Senecioneae) no Rio Grande do Sul - Brasil. Tese de Doutorado. Universidade Federal do Rio Grande do Sul, Porto Alegre. 274p.

Matzenbacher, N.I. 2009. Uma nova espécie do gênero Senecio L. (Asteraceae - Senecioneae) no Rio Grande do Sul, Brasil. Iheringia: Botanica 64: 109-113.

Matzenbacher, N.I. \& Baptista, L.R.M. 1997. Uma nova combinação no gênero Dendrophorbium (Cuatrec.) C. Jeffrey (Asteraceae - Senecioneae). Boletim do Museu Botânico Prefeitura Municipal de Curitiba, MBM 65: 1-3.

Moraes, M.D. \& Monteiro, R. 2006. A família Asteraceae na planície litorânea de Picinguaba, Ubatuba, São Paulo. Hoehnea 33: 41-78.

Nicolson, D.H. 1980. Summary of cytological information on Emilia and the taxonomy of four Pacific taxa of Emilia (Asteraceae: Senecioneae). Systematic Botany 5: 391-407.

Nordenstam, B. 1978. Taxonomic studies in the tribe Senecioneae (Compositae). Opera Botanica 44: 1-83.

Nordenstam, B. 1994. New transfers to Graphistylis B. Nord. (Senecioneae). Compositae Newsletter 24: 50-51.

Nordenstam, B. 2007. XII. The tribe Senecioneae Cass. 1819. In: Kadereit, J.W. \& Jeffrey, C. (eds.). The families and genera of vascular plants. Flowering plants, Eudicots, Asterales. Berlin. Springer 8: 208-241.

Nordenstam, B.; Pelser, P.B.; Kadereit, J.W. \& Watson, L.E. 2009. Senecioneae. In: Funk, V.A.; Susanna, A.; Stuessy, T.F. \& Bayer, R.J. (eds.). Systematics, evolution and biogeography of Compositae. International Association for Plant Taxonomy, Vienna. Pp. 503-525.

Pelser, P.B.; Nordenstam, B.; Kadereit, J.W. \& Watson, L.E. 2007. An ITS phylogeny of tribe
Senecioneae (Asteraceae) and a new delimitation of Senecio L. Taxon 56: 1077-1104.

Pruski, J.F. 1996. Pseudogynoxys lobata (Compositae: Senecioneae), a new species from Bolivia and Brazil. Systematic Botany 21: 101-105.

Pruski, J.F. 1997. Asteraceae. In: Berry, P.E.; Holst, B.K. \& Yatskievych, K. (eds.). Flora of the Venezuelan Guayana 3: 177-393.

Robinson, H. 1980. Studies in the Senecioneae (Asteraceae). X. A new species of Senecio from Brazil. Phytologia 46: 293-294.

Robinson, H. \& Cuatrecasas, J. 1977. Notes on the genus and species limits of Pseudogynoxys (Greenm.) Cabrera (Senecioneae, Asteraceae). Phytologia 36: 177-192.

Robinson, H. \& Cuatrecasas, J. 1978. A review of the Central American species of Pentacalia (Asteraceae: Senecioneae). Phytologia 40: 37-50.

Teles, A.M. 2010. Nova combinação e chave revisada para Dendrophorbium (Asteraceae - Senecioneae) no Brasil. Rodriguésia 61: 143145 .

Teles, A.M. \& Freitas, F.S. 2013. Senecio hortensiae (Asteraceae, Senecioneae): a new species from Espírito Santo, Brazil. Phytotaxa 142: 46-50.

Teles, A.M. \& Meireles, L.D. 2010. A new species of Senecio (Asteraceae: Senecioneae) from southeastern Brazil. Brittonia 62: 178-182.

Teles, A.M.; Nakajima, J.N. \& Stehmann, J.R. 2006. Dendrophorbium restingae (Asteraceae: Senecioneae), a new species from São Paulo, Brazil. Sida 22: 123-128.

Teles, A.M.; Nakajima, J.N. \& Stehamann, J.R. 2009. Senecio albus, a new species of Senecio sect. Adamantina (Senecioneae - Asteraceae) with an emendment to the section. Kew Bulletin 64: 161-165.

Teles, A.M. \& Stehmann, J.R. 2008. Plantae, Magnoliophyta, Asterales, Asteraceae, Senecioneae, Pentacalia desiderabilis and Senecio macrotis: distribution extensions and first records for Bahia, Brazil. Check List 4: 62-64.

Teles, A.M. \& Stehmann, J.R. 2011. Flora da Serra do Cipó, Minas Gerais: Asteraceae - Senecioneae. Boletim de Botânica da Universidade de São Paulo. São Paulo 29: 57-68.

Thiers, B. 2015. Index Herbariorum: a global directory of public herbaria and associated staff. New York Botanical Garden's Virtual Herbarium. Disponível em $<$ http://sweetgum. nybg.org/ih/>. Acesso em 7 março 2015.

Vincent, P.L.D. 1996. Progress on clarifying the generic concept of Senecio based on an extensive world-wide sample of taxa. In: Hind, 
D.J.N. \& Beentje, H.J. Compositae: systematics. proceedings of the international compositae conference. Royal Botanic Gardens, Kew. Pp. 597-611.

Vincent, P.L.D. \& Gentliffe, F.M. 1992. Elucidative studies on the generic concept of Senecio
(Asteraceae). Botanical Journal of the Linnean Society 108: 55-81.

Zardini, E.M. 1979. Una nueva especie del género Senecio L. (Compositae) de Brasil. Boletim do Museu Botânico Prefeitura Municipal de Curitiba, MBM 37: 1-5. 